\title{
A estratégia territorial da Colônia Militar do Itapura: legado urbano e arquitetônico
}

Itapura's military colony territorial strategy: urban and architectural legacy

hitps://doi.org/10.1590/1982-02672020v28e20

\author{
NILSON GHIRARDELLO' \\ htips: / / orcid.org/0000-0002-9347-4795 \\ Universidade Estadual Paulista "Júlio de Mesquita Filho" / Bauru, SP, Brasil
}

\section{DANIEL CANDELORO FERRARI²}

https: / / orcid.org/0000-000 1-8793-2828

Universidade Estadual Paulista "Júlio de Mesquita Filho" / Bauru, SP, Brasil

RESUMO: Em meados do século XIX o governo imperial empregou um plano de ocupação do território nacional através da criação de colônias militares. Assim, a fundação desses estabelecimentos por todo o império vincula-se aos problemas relacionados ao controle e domínio social, numa época em que a manutenção da integridade territorial e, simultaneamente, uma perspectiva de expansão das fronteiras colocaram-se como sendo das mais emergenciais entre as tarefas das elites políticas. Itapura e Avanhandava foram as duas colônias criadas na província de São Paulo e herdaram o topônimo de seus locais estratégicos de implantação - os saltos no Rio Tietê. $O$ presente trabalho tem como propósito estudar a colônia militar do Itapura em seu aspecto espacial-construtivo. O objetivo é analisar o material textual e cartográfico da colônia, documentação coletada em arquivos públicos, principalmente plantas e projetos, trazendo à luz tal fonte primária. Dessa forma, com clara intenção de planejamento urbanístico, demonstra-se

\begin{abstract}
1. Doutor em Arquitetura e Urbanismo pela Faculdade de Arquitetura e Urbanismo da Universidade de São Paulo. Atualmente é Professor do Departamento de Arquitetura, Urbanismo e Paisagismo e do Programa de Pós Graduação em Arquitetura e Urbanismo da Faculdade de Arquitetura, Artes e Comunicação da Universidade Estadual Paulista "Júlio de Mesquita Filho" (Faac/ Unesp) - Campus de Bauru. E-mail: <nilson.ghirardello@ unesp.br>

2. Mestrando em Arquitetura e Urbanismo da Faac/Unesp - Campus de Bauru. Possui graduação em Arquitetura e Urbanismo pelo Centro de Tecnologia e Urbanismo da Universidade Estadual de Londrina (CTU/UEL). E-mail: <dcanferrari@gmail.com>
\end{abstract}


um ideal que estava muito além de demarcar e ocupar a região: o intuito era construir em meio à mata fechada e às margens do Rio Tietê uma cidade projetada, inicialmente de caráter militar e agrícola, que seria a semente de futuro núcleo civil. Além disso, ao compararem-se as plantas da colônia do século XIX com as imagens de suas ruínas, fotografadas pela Comissão Geográfica e Geológica de São Paulo no início no século XX, verifica-se a exuberância arquitetônica de suas construções e a qualidade urbanística de seu plano considerado inovador para a época.

PALAVRAS-CHAVE: Colônia militar. Itapura. Avanhandava. Colonização militar. Ocupação territorial paulista.

ABSTRACT: In the mid-nineteenth century the imperial government employed a plan of occupation of the national territory through the creation of military colonies. Thus, the foundation of these settlements throughout the empire is connected to the problems related to social control and domination, at a time when the maintenance of territorial integrity and, at the same period, a perspective of expansion of the frontiers were posed as most urgent among the tasks of political elites. Itapura and Avanhandava were the two colonies in the province of São Paulo and inherited the homonyms of their strategic implantation sites - the waterfalls of the Tietê river. This paper aims to study the military colony of Itapura in its spatial-constructive aspect. The objective is to analyze the textual and cartographic material of the colony, documentation collected in public archives, mainly plans and projects, bringing to light such primary source. Therefore, with an evident intention of urban planning, it demonstrates that was an ideal that was beyond demarcating and occupying the territory: the aim was to build a projected city, initially with military character and on the banks of the Tietê, which would be the seed of future civil nucleus. Moreover, by comparing the plans of the 19th century colony with the images of its ruins, photographed by the Geographical and Geological Committee of São Paulo in the early 20thcentury, we can verify the architectural exuberance of your buildings and the urban quality of your plan, which is considered innovative for the age.

KEYWORDS: Military colony. Itapura. Avanhandava. Military colonization. Paulista territorial occupation. 
"O Brasil sempre teve problemas com o espaço". ${ }^{3}$ Longe de ser uma questão de pouco espaço, o Império brasileiro apresentava um território com dimensões continentais. Sua dificuldade foi a existência de vastas regiões, consideradas pelo homem branco como terras "desocupadas, pouco exploradas e indomáveis". É possível dizer que a falta de conhecimento sobre os recursos e o potencial dessas áreas envolveram muitas regiões do Brasil no "mistério". Expectativas e intenções para a conquista de um "eldorado" tentaram se viabilizar desde períodos coloniais. Os sonhos de riqueza, enterrados em algum lugar dentro desse inconsciente, geraram forças poderosas que atraíam indivíduos, grupos e governos em um grande esforço para se aproveitarem de tais recursos. Alguns alcançaram sua busca, mas muitos falharam enquanto desperdiçavam forças na variedade e alcance de seus planos.

Basta olhar para a cartografia da Província de São Paulo do século XIX até o início do XX, onde hoje se encontra o atual oeste do Estado, que se pode encontrar expressões controversas como "sertão desconhecido", "terras não exploradas", "terrenos desconhecidos habitados pelos indígenas", entre outras. Novamente frisando, desconhecido e não explorado pelo homem branco. Mas ora, "que episódio de 'história gloriosa', em não importa que país, deixará de estar manchado por algum crime?"4

Em São Paulo, por volta da metade do século XIX e até princípio do XX, já se encontrava em pleno reinado e expansão o capitalismo industrial, em escala mundial: ferrovias, telégrafos, companhia de hipoteca de terras e companhias comerciais [...] As populações primitivas, isto é, os diferentes grupos étnicos existentes, não eram mais vistos como um reservatório de mão-de-obra, mas detentores de um meio de produção vital à economia baseada na propriedade da terra. Essa questão passou a ser, portanto, o grande móvel das tensões entre uma sociedade e outra. Se por um lado, a penetração econômica nas novas terras significava produção de novas mercadorias e ampliação de lucros, para o índio significava a destruição do seu modo de vida e de sua estrutura social; enfim, de sua cultura. ${ }^{5}$

Pedro II herdou, precocemente, um império envolto por uma multiplicidade de problemas. As fronteiras brasileiras estavam mal protegidas e ainda não materializadas, as grandes distâncias e a dificuldade de comunicação bloquearam vários esforços para proteger a integridade nacional. Vastas extensões de terras cultiváveis, consideradas como principal recurso natural da época, estavam "desocupadas". Parte da população exigia uma melhor proteção contra os perigos inerentes à vida em regiões "selvagens". Em meados do século XIX, o grande projeto do governo imperial (1840-1889) consistia em colonizar o Brasil em todos os 
6. Oliveira (2017).

7. Cf. Janke (2014).

8. Mattos (2004, p. 736). quadrantes, defender as fronteiras, abrir, melhorar e proteger as vias de comunicação, "integrar os índios à civilização" e desenvolver a agricultura e o comércio.

Para Oliveira, estabelecer colônias militares pelo território carregava uma dimensão colonizadora e transformava, grosso modo, o governo imperial em "metrópole" que precisava viabilizar a conquista e a ocupação da superfície nacional. ${ }^{\circ}$ Dessa maneira, expandir-se sobre os sertões era fundamental no processo de negociação dos limites do império com as repúblicas vizinhas, garantindo assim a soberania do Estado.7 Nas palavras de Mattos, "O Estado imperial deveria empreender uma expansão para dentro, de modo permanente e constante, indo ao encontro dos brasileiros que forjava". ${ }^{8}$ E era em tal expansão que residia o traço mais significativo na construção de uma unidade: devido a isso, o atributo central que vai adquirir destaque no processo de organização e consolidação do Império como Estado-nação soberano é o território.

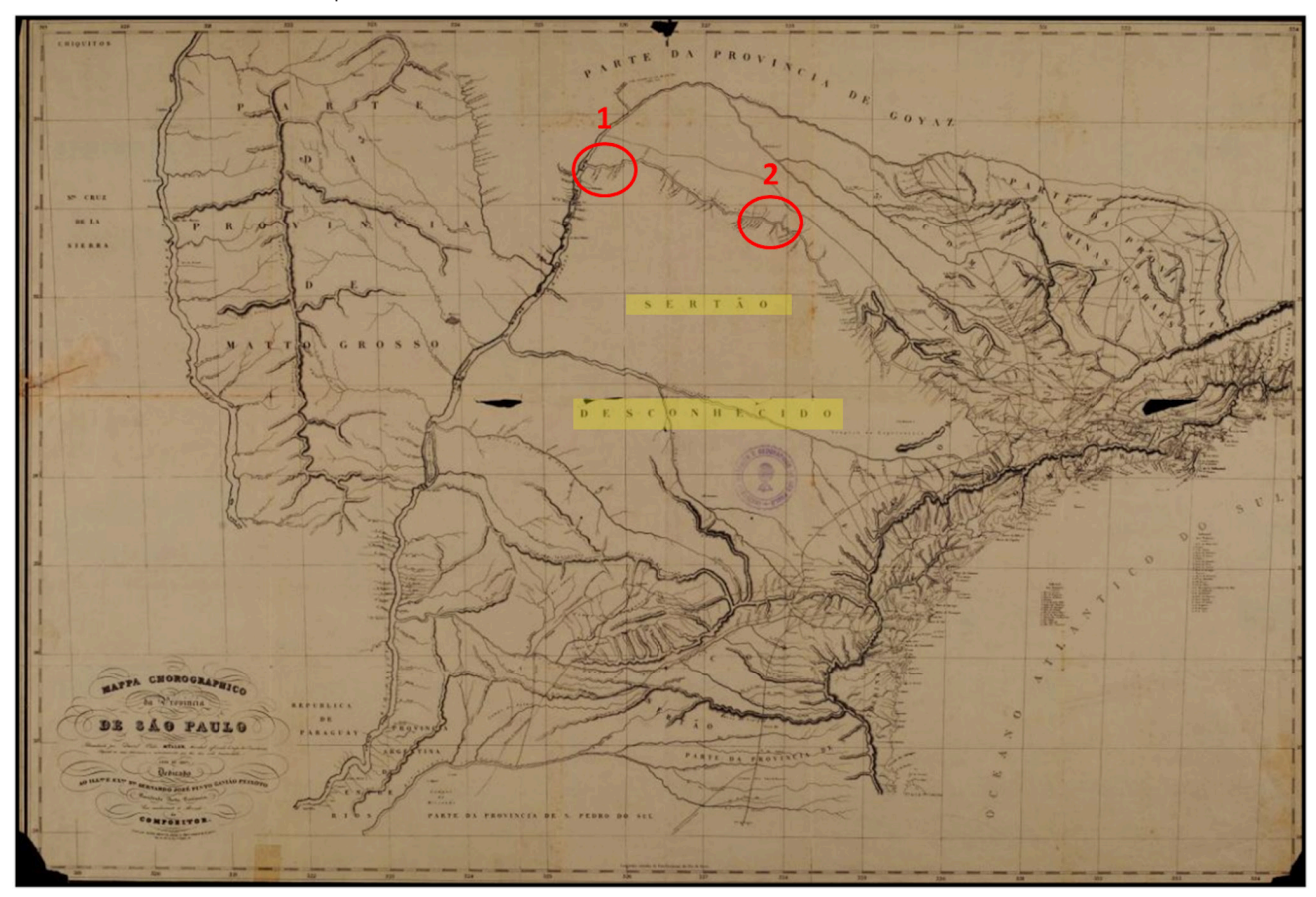

Figura 1 - Mappa Chorographico da Provincia de São Paulo, 1841, por Daniel Pedro Müller. Observar a expressão "Sertão Desconhecido" com destaque em amarelo, e círculos vermelhos com a localização das futuras colônias militares: 1. Salto do ltapura; 2. Salto do Avanhandava. Fonte: BEIER, 2013. Acervo do Arquivo Público do Estado de São Paulo, editado pelos autores, 2019.

importante é salientar que, antes da formação dos povoados, transformados posteriormente em cidades, antes mesmo dos planos "desbravadores" da construção da Companhia Estrada de Ferro Noroeste do Brasil (Cefnob), precursora na região, existiram algumas tentativas de abertura 
e ocupação do território no "Sertão Desconhecido" (ver figura 1), chamado

9. Cf. Silva (1972).

10. Cf. Cintra; Beier; Rabelo (2018).

11 Cf. Derntl (2010).

12. Cf. Holanda (2014).

\section{O RIO TIETÊ E AS ESTRATÉGIAS DE OCUPAÇÃO TERRITORIAL}

Era patente a necessidade de assegurar o domínio na região ocidental do Brasil. ${ }^{9}$ Os saltos do Avanhandava e Itapura (figura 1) eram considerados locais estratégicos devido ao processo de varação - onde os viajantes deveriam retirar as embarcações do curso de água e transpassarem por terra, descrito como penoso trabalho que consumia muito tempo, até mesmo alguns dias. Tais saltos são representados, possivelmente pela primeira vez, em um dos mais antigos e pitorescos documentos cartográficos do território paulista, o mapa da viagem de D. Luís de Céspedes Xeria da vila de São Paulo de Piratininga a Ciudad Real del Guayrá, na província do Paraguai, em 1628.10 Demonstrando, assim, a importância dos dois saltos desde a época colonial, tendo passado por períodos de intensa navegação, como o das monções.

Portanto, devido possuir um caminho natural para adentrar-se ao interior do país, o Rio Tietê foi alvo de esforços e planos oficiais de povoações, elaborados durante o século XVIII durante o governo de D. Luis Antonio de Sousa Botelho Mourão, o quarto morgado de Mateus. Uma dessas estratégias foi a criação do Presídio de Nossa Senhora dos Prazeres e São Francisco de Paula do Iguatemi, ou simplesmente "Forte do Iguatemi", que fora concebido como "porta" que impediria a entrada dos espanhóis pelo oeste da colônia. Além disso, colonizado por paulistas, o forte auxiliaria a assegurar a rota de navegação a Cuiabá pelos rios Paraná e Pardo. Com função defensiva, o lguatemi era parte de uma estratégia de avanço da colonização, que, em conjunto com outra fortificação prevista no Rio Ipané, mais a oeste, almejava-se dominar a navegação do Rio Paraguai. $\bigcirc$ povoamento da região seria realizado com fazendas de gado e sítios, sem descartar ainda a viabilidade de comércio ilegal com os espanhóis. ${ }^{11}$

Para Holanda, ${ }^{12}$ o primeiro passo a superar os diversos empecilhos numa empreitada dessa envergadura estaria no estabelecimento de condições capazes de garantir o mínimo de segurança à navegação fluvial. $\bigcirc$ desejo de povoar 
13. Neme (2009, p. 59).

14. Ibid. aqueles sertões começava, se possível, a transformar o acidentado Anhembi - era necessário para isso fixar população nas barras principais e junto aos sítios em que se fazia mais perigosa navegação. A intenção era criar povoados nas margens e ao longo do Rio Tietê, até sua embocadura no Paraná, notadamente nas regiões de corredeiras e saltos: Piracicaba, Avanhandava e Itapura. Estas facilitariam o transporte das expedições que iam sempre carregadas de provisões e armamentos, além de formar portos de reabastecimento para as tropas a caminho do lguatemi. Em 1768 cuidava D. Luis Antonio de realizar o povoamento do vale do Tietê, e em janeiro, escrevia ao povoador de Piracicaba, Antonio Corrêa Barbosa:

ajudante Manuel José Alberto entregará a vmcê., os presos vagabundos que constam na relação por mim rubricada; de que vmcê. deve tomar conta e fazer-lhe assentos de suas naturalidades. Com os mesmos, irá vmcê. povoar na margem do rio Tietê os sítios de Avanhandava, barra de Piracicaba, e Itapura, e os mais que forem convenientes para bem dos povos, na forma que vmcê. deve participar para que tudo se execute na forma que determino. Dessa povoação assistirá vmcê. com alguns mantimentos aos homens, e com alguma ferramenta para os serviços $[\ldots] .^{13}$

Assim, com o auxílio daquela população, pretendia a administração colonial lançar sementes de um plano pretensioso que teria por objetivo transformar o Rio Tietê em uma verdadeira linha estratégica para a ocupação bem-sucedida do oeste e sudoeste. Porém, os primeiros entusiasmos do governador logo esvaeceram à notícia das várias dificuldades que encontravam seus ajudantes. $\bigcirc$ pessoal que ele dispunha era insuficiente para tamanha realização, e a situação no sul do país "ia de mal a pior", em face da crescente ameaça castelhana. Conforme Neme, ${ }^{14}$ foram inevitáveis os impasses que o morgado de Mateus encontrara para a realização de seu intento. Ninguém consentia aos convites para ir povoar aquelas paragens, alegando que tais lugares eram pestilentos, e o solo, incultivável. Mesmo a facilidade no tocante à concessão de sesmarias marginais ao Tietê abaixo não era aproveitada pelo pessoal, que preferia estabelecer-se nos povoados mais adiantados. $\bigcirc$ Rio Tietê teve um papel essencial para o processo de ocupação territorial do interior da colônia portuguesa. Seu percurso, de rumo contrário à costa, propício à navegação a favor da corrente, foi o principal meio de acesso, as chamadas monções e incursões científicas aos sertões paulistas, e permitiu a expansão territorial e humana, além da penetração para a descoberta de riquezas minerais durante os séculos XVII e XVIII. Assim, o império brasileiro considerava que o principal acesso, que partia de São Paulo, em direção a Mato Grosso, era o Rio Tietê (antigo Anhembi). Dessa maneira, iria definir em suas 
margens as duas colônias militares da província: Avanhandava e ltapura, evitando com isso invasões e implantando postos de comando e policiamento.

No final do século XVIII, ao assumir a administração da Capitania de São Paulo, o capitão-general Antonio Manuel de Mello Castro e Mendonça novamente cogitou povoar ao longo do Rio Tietê. Os objetivos dessa realização eram semelhantes aos dos primeiros planos colonizadores: principalmente socorrer os viajantes que se destinassem a Cuiabá e Mato Grosso, além de facilitar e promover a pronta e eficaz comunicação com as fronteiras e sua defesa. Para executar a tarefa, foi escolhido o tenente-coronel Candido Xavier de Almeida e Souza. ${ }^{15}$

O plano ${ }^{16}$ desse oficial, elaborado nos últimos anos do século XVIII, consistia em fundar quatro povoações junto ao Rio Tietê: a primeira na região de Potundava, onde se instalariam casais de povoadores, com suprimentos de alimentação, ferramentas para lavrar a terra e algumas cabeças de gado; a segunda seria erguida no Salto do Avanhandava (ver figura 2); a terceira junto ao Salto do Itapura (figura 3); a quarta seria estabelecida perto do Rio Paraná, na desembocadura do Rio Pardo, com o intuito de ponto de apoio aos navegantes que se dirigissem a Cuiabá e outras minas de Mato Grosso. As povoações deveriam fixar-se em sítios afastados do rio, a fim de evitar epidemias, o que ocorria com frequência em época de vazante. A localização das povoações de Avanhandava e Itapura deveria ser cuidadosa e estrategicamente pensada devido às corredeiras que de antemão exigiam a retirada das embarcações (canoa caiçara, canoa monóxila) das águas - processo penoso conhecido como varação. Fundar oficialmente os povoados não bastava, era necessário atrair para os arredores uma população estável, que fornecesse vida e progresso aos arraiais e às vilas. Porém isso não acontecera. De acordo com Holanda, ${ }^{17}$ não consta que as propostas do tenente-coronel Cândido Xavier tivessem merecido maior interesse do que as do morgado de Mateus. Para Bacellar, ${ }^{18}$ os povoados de Avanhandava e ltapura nem mesmo chegaram a sair do papel. Ainda, segundo Silva, ${ }^{19}$ todos os esforços enviados para povoamento dos vales do Paraná e do Tietê, durante o século XVIII, não foram além de planos teóricos.

Os maiores empecilhos para a fixação do homem branco eram o agreste dos sertões, os "selvagens", e as inúmeras doenças que grassavam às suas margens. $\bigcirc$ deslocamento de certo número de colonos para aquelas paragens, notoriamente pestilentas, separadas por vários quilômetros até a vila ou freguesia mais próxima, como Piracicaba, ou Porto Feliz - que eram até onde o povoamento branco chegara -, seria dificilmente praticável durante a época das monções. Somente após esvaecer o trânsito fluvial do Tietê é que, para fins militares, foram efetuadas as primeiras tentativas concretas de povoamento da região: as colônias militares de Itapura e Avanhandava, já nos meados do século XIX.
15. Cf. Silva (op. cit.).

16. Holanda (2014, p. 57).

17. Cf. Holanda (2014).

18. Cf. Bacellar (2017).

19. Cf. Silva (op. cit.) 


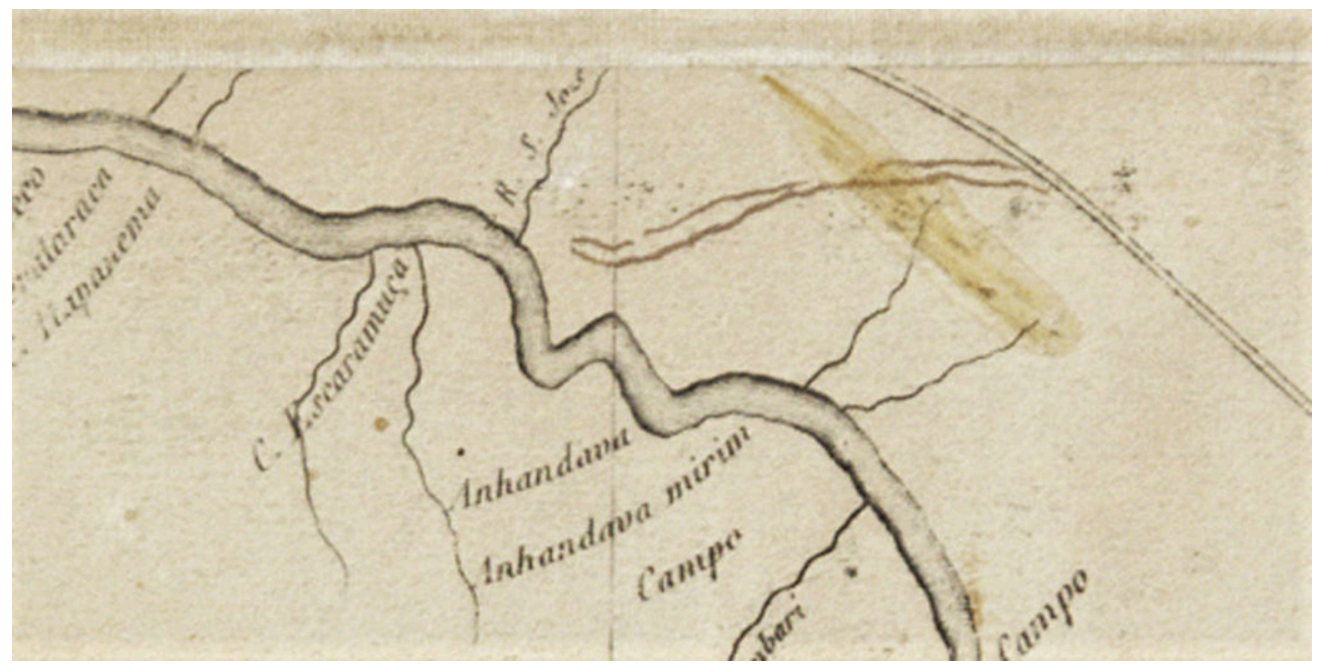

Figura 2 - Detalhe 2 da figura 1. Notar as expressões Avanhandava e Avanhandava mirim - Mappa Chorographico da Provincia de São Paulo, 1841, por Daniel Pedro Müller Fonte: Acervo da Fundação Biblioteca Nacional do Rio de Janeiro, editado pelos autores, 2019

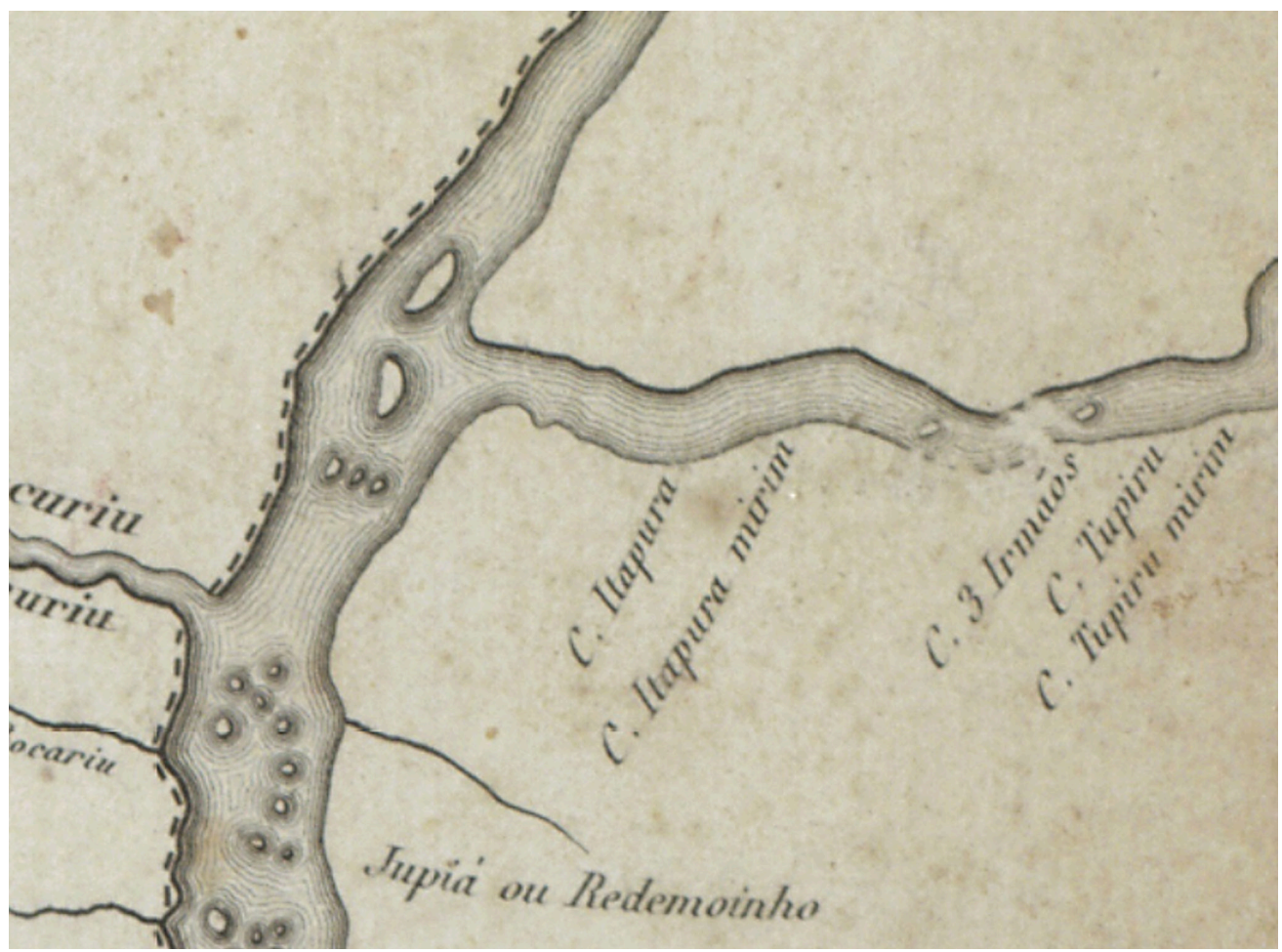

Figura 3 - Detalhe 1 da figura 1. Notar as expressões ltapura e ltapura mirim, que correspondem a saltos diferentes - Mappa Chorographico da Provincia de São Paulo, 1841, por Daniel Pedro Müller. Fonte: Acervo da Fundação Biblioteca Nacional do Rio de Janeiro, editado pelos autores, 2019. 
A preocupação de colonizar, no sentido de ocupação produtiva capitalista e fixação do homem branco ao solo, era tão importante naquele momento histórico (meados do XIX) que se cuidava de propor incentivos aos povoadores para estes migrarem com suas famílias. As políiticas de aldeamentos, construção de estradas, picadões e apoio às expedições que acabavam por expulsar ou exterminar os povos indígenas tinham como objetivo a formação de grandes propriedades e a consequente valorização das terras da região. É assim que, na metade dos Oitocentos, o plano de larga visão de colonização militar do império foi posto em prática. E no caso de São Paulo, o Rio Tietê era considerado o principal acesso em direção a Mato Grosso, portanto deveria ser resguardado, evitando-se com isso invasões, e a implantação de postos avançados de comando e policiamento. Nessa conjuntura resolveu o governo - mais especificamente, a ordem foi do então ministro da Marinha, José Antônio Saraiva, já com intenções de criar um estabelecimento naval na foz do Rio Tietê - enviar para a Província de São Paulo Antônio Mariano de Azevedo, jovem oficial da marinha que fez uma incursão ao Rio Tietê até o sertão de ltapura em 1857 para averiguar as possibilidades de criação de centros povoadores, além de reconhecer locais estratégicos para sediar o estabelecimento naval.

O resultado da expedição ao Rio Tietê foi o "Relatório do Primeiro Tenente d'Armada Antonio Mariano de Azevedo, sobre os exames que fui incumbido no interior da província de São Paulo", publicado em 1858. Segundo Mariano, o relatório era dividido em três partes. A primeira iria expor todas as medidas que tomara para facilitar o transporte do vapor (navio Tamandatahy) - que o governo imperial desejava colocar no Alto Paraná -, as despesas exigidas e sobre a fundação de um estabelecimento naval na foz do Rio Tietê. A segunda seria a descrição, o roteiro da viagem que fez pelos rios Piracicaba e Tietê - lembrando que a expedição partiu da cidade da Constituição (atual Piracicaba) através desses rios até chegar aos sertões de Itapura. E, por fim, a terceira faria as considerações finais "motivadas por tudo quanto vi e apreciei, e com ellas esforçar-me-ia por demonstrar a utilidade da grande idéa, que o patriotismo e a ilustração suggerirão ao Exm. Sr. Ministro da marinha". ${ }^{20}$ Contudo, ele decide retirar "do todo do relatório as duas partes que ião aumenta-lhe a esterilidade, e inclui na ultima o que das primeiras me pareceu aproveitável".

Assim, Mariano inicia seu texto revelando o desconhecimento de nossos cursos de água: "Os nossos rios interiores, atravessando centenas de legoas de despovoados sertões, são em geral tão pouco conhecidos, que não admira o estado de ignorancia em que nos achamos a seu respeito, e o quasi abandono em 
21. Ibid., p. 5.

22. Ibid., p. 5-6.

23. Ibid., p. 20.

24. Cf. Gonzaga da Silva (2017).

25. Id. (2015). que até hoje tem elles jazido."21 Retrata, ainda, que o Rio Tietê poderia ser mais lembrado e menos desconhecido: devido às muitas vezes que foi utilizado para as incursões que tinham como destino a província de "Matto-Grosso", para a exploração de ouro, circunstâncias estas de um valor histórico-político incontestável:

Parece pois que um rio em taes condições deveria ha muito ter feito aquilatar as vantagens e desvantagens que nelle se póde encontrar, máxime se nos recordarmos de que pertencemos a um paiz, onde a falta de communicações é a causa da retardação da sua prosperidade, e do seu poder. Mas não acontece assim. As cousas tem marchado de tal modo, que o Tieté é hoje menos conhecido do que nos tempos coloniaes. ${ }^{22}$

O autor delibera sobre a comunicação fluvial que, durante o século XVIII, foi estabelecida entre São Paulo e Cuiabá, e deveria ser novamente retomada para integrar a província de Mato Grosso à Corte. Além disso, defende a navegação dos rios "interiores", inclusive, para acabar com a dependência da rota estrangeira pela bacia do Prata. $O$ isolamento geográfico e a economia desenvolvida pela província (sem elevados níveis de exportação e muito mais próxima aos vizinhos latinos) ameaçavam suas relações com o resto do país. Dessa forma, contribuindo para a possibilidade de separação - caso o governo argentino, ou outras repúblicas "invejosas", como diz Mariano, expandissem seus comércios com a província de Mato Grosso, por exemplo. Ora, "quem poderá assegurar que os habitantes de Mato-Grosso acharão muito vantajosa a continuação de sua existencia politica entre a communidade brasileira? [...] Esta verdade geographica-politica não pode continuar a ser-nos indiferente" ${ }^{23}$

De acordo com Gonzaga da Silva, ${ }^{24}$ o discurso do oficial Antonio M. de Azevedo ia ao encontro de diversos políticos brasileiros: defender a província de Mato Grosso significava estimular sua ocupação, comércio e integração. Considerando o comércio argentino e a presença paraguaia como elementos ameaçadores na região, o plano estratégico para construção do estabelecimento naval foi ampliado ao sugerir a adoção do sistema de colônias agrícolas e militares a fim de desenvolver o comércio, o povoamento e a civilização no interior. ${ }^{25}$ Dessa maneira, Azevedo julgava como boa proposta fundar na margem direita do Salto do Itapura um estabelecimento naval-militar, e em outras localidades, colônias agrícolas-militares, como é o caso do Salto do Avanhandava.

Tudo quanto acabo de dizer póde mostrar o grande alcance da idéa de fundar um estabelecimento naval na foz do Tieté, e de fazer navegar pelo Alto Paraná alguns vapores do Estado. $\bigcirc$ estabelecimento do Itapura não é só de grande importancia estrategica, no caso de sermos forçados a uma guerra pela impertinencia de algum de nossos vizinhos. Elle é tambem a primeira manifestação dessa iniciativa do governo de que eu ha um instante falei: será como que as 
vertentes dessas torrentes de brasileirismo que tem de regar o coração de Mato-Grosso, e de espalhar em todo o seu territorio os grandiosos fructos da nossa patriotica união.

[...] Bem se vê que ao estabelecimento do Itapura devem seguir-se outros nucleos de população que reproduzão em maior escala os resultados que se forem obtendo daquelle. E para o futuro, quando desaparecerem os actuaes sertoes banhados pelos rios acima citados, para darem lugar a boas e transitadas estradas, que comuniquem entre si proximas e florescentes povoações, uma politica sábia e patriotica [... $]^{26}$

A escolha da região do ltapura recaía aos diversos critérios estratégicos: terras férteis para agricultura, abundância de madeiras para construção naval, possibilidade de construção de estradas ligando o interior da Província de São Paulo, incentivo à povoação no Alto Paraná:

O lugar que escolhi para a fundação da colonia naval é excellente em todos os sentidos. Além de gozar de todas as condições de salubridade, possue as mais férteis terras do mundo. Mas cumpre mandar quanto antes para ali braços agricultores, que poupem ao governo as enormes despesas que se farão se se comprar em Piracicaba os gêneros de alimentação dos colonos $[\ldots]^{27}$

\section{A respeito de Avanhandava, Mariano de Azevedo escreve:}

Finalmente, um elemento civilisador de grande eficcacia seria a creação de uma colonia agricola, ao lado esquerdo do salto do Avanhandava. Para as vizinhanças daquella localidade, dirige-se actualmente uma emigração de sertanejos de Minas, attrahidos pela superioridade das terras, pela facilidade com que ali fazem as suas posses. Durante os tres dias que passei no lado direito, presenciei a emigração de uma dessas famílias [...]

Uma colonia agricola, que se fundar no lado esquerdo do salto do Avanhandava, encontrará terrenos os mais ferteis do mundo, e uma via fluvial para a exportação dos seus productos, em quanto não houver uma boa estrada [...]

O lugar mais apropriado e vantojoso para a fundação de uma colonia agricola é o lado esquerdo do proprio salto do Avanhandava. Ella poderá remetter facilmente pelo rio os seus productos, depois que no systema de navegação actualmente em uso se adoptar as reformas que proponho. Seria muito conveniente que a colônia fosse composta de lavradores, e artistas alemmães. ${ }^{28}$

Pelas razões citadas acima, Azevedo acreditava de urgência a criação de uma colônia agrícola com bases militares, considerada o único meio de oferecer tranquilidade aos habitantes dos chamados campos de Avanhandava. $\bigcirc$ oficial pensava que assim poderia o governo ser capaz de atrair, além dos colonos nacionais, imigrantes estrangeiros (alemães principalmente) que, "intelligentes e laboriosos", trariam progresso à região de solo fértil e de fácil comunicação até Piracicaba. Apesar de
26. Azevedo (op. cit., p. 22-23).

27. Ibid., p. 49.

28. Ibid., p. 44-45,48. 
29. Silva (op. cit., p. 9).

30. Cf. Ghirardello (2006).

31. Azevedo (op. cit., p. 21).

32. Ibid., p. 35. indicar o lado esquerdo do Avanhandava para a fundação da colônia, esta seria implantada no lado direito - por onde se dava o processo de varação e onde se localizava a estrada que saía de Piracicaba em direção a Sant'Anna do Parnahyba (província de Mato Grosso). Funcionando como local de apoio e proteção àqueles que trafegassem tanto por via fluvial quanto por via terrestre através da dita estrada. Assim, segundo Silva, o depoimento de Mariano de Azevedo quanto ao povoamento da região foi extremamente importante: "em sua longa jornada, percebeu que as margens do rio Piracicaba já estavam amplamente povoadas e o mesmo ocorrendo no Vale do Tietê até Guaimicanga, 29 quilômetros acima do Avanhandava". ${ }^{29}$

No parecer de Azevedo fica definida a importância destes estabelecimentos como pontos de relação e integração com a capital da província; nunca como sítios isolados, imaginando-os e juntando esforços para que se constituíssem como venturos centros urbanos, importantes e salubres, bem como áreas de produção agrícola relevante. ${ }^{30}$ Pensando em incrementar a atividade agrícola nas regiões, determinava-se que todos os colonos e operários poderiam, após preencher certos requisitos, requerer lotes no distrito colonial, e mais tarde até os "africanos livres" teriam esse direito.

Assim, Mariano também defendia a ideia de uma colônia militar-agrícola que, logo, entraria em um sistema de distribuição de pequenas propriedades de terras:

Estou persuadido de que um futuro, talvez bem proximo, resolverá o problema extinguindo a grande propriedade. Esse velho resto do feudalismo, e do regimen colonial não poderá substituir por muito tempo ainda em um paiz como o nosso, onde tanta preponderancia, e estabilidade se deu ao elemento democratico, e cuja população será por longos annos escassa, em relação à extensão do seu territorio. ${ }^{31}$

Mariano propõe, entre outras melhorias, a construção de uma estrada marginal que vá de Avanhandava a ltapura, como forma de incentivo à atração de habitantes para as povoações, e principalmente para facilitar a comunicação entre as duas colônias. Em seu plano, divide o Tietê em duas partes: uma como inavegável, outra como navegável. A primeira compreende o trecho entre o salto de Avanhandava e a foz do Rio Tietê, que, segundo ele, contém 18 cachoeiras, sendo quase todas perigosas e trabalhosíssimas pelo completo descarregamento e contínuas varações por terra que obrigam a fazer. A segunda é a parte compreendida entre a foz do Rio Piracicaba e o salto do Avanhandava, "cujas caxoeiras são pouco espinhosas, à excepção de trez, que comtudo, em risco e difficuldades, não tem comparação com as da parte inferior áquelle salto". ${ }^{32}$

Apreciando devidamente estas circumstancias, e procurando tirar dellas um resultado vantajoso, no sentido de dar brevidade á realisação das vistas do Exm. Ministro da Marinha, fiz ver a S. Exc. o quanto seria util mandar principiar desde já a factura de uma 
estrada, que ligue os dois saltos de que me tenho occupado. A vantagem que tive em vista obter salta aos olhos. Uma estrada de Piracicaba ao Avanhandava exigirá para sua promptificação muito mais tempo, trabalho, e dispendio do que uma do Avanhandava ao Itapura [...] Ora, se se principiasse pela primeira, as coisas continuarião [...] a necessidade de navegar a parte ruim do Tieté, que eu chamei innavegavel. Ao passo que, principiando pela segunda, ficaremos libertados das prejudiciaes varações dos saltos daquelle rio, e dos perigos e trabalhos das bravas caxoeiras da sua metade inferior, por quanto em seu lugar encontrar-se-ha um commodo e breve transito por terra. ${ }^{33}$

O relatório elaborado pelo oficial da marinha foi, dessa maneira, importante para determinar a localização das futuras colônias militares - que serão criadas, por decretos de lei, no ano de 1858. O texto é fonte histórica que nos fornece subsídios para compreender as ações do Ministério da Marinha, investindo na criação de estabelecimento naval próximo à foz do Rio Tietê, e atribuindo diretrizes de localizações para criar outras colônias agrícolas-militares. Além disso, promove uma interprełação geopolítica, relacionando o território e o poder, a situação conflituosa entre as repúblicas vizinhas, explicando a necessidade de colonizar o interior do país (com caráter estratégico), para integrar não só a Província de Mato Grosso, mas o próprio oeste da Província de São Paulo, fazendo uma conexão entre vias fluviais e terrestres. Porém, apesar da boa intenção de Mariano e suas diretrizes, parece ter-se esquecido que para cumpri-las exigia-se muito mais do que somente o simples discurso. Não levando em conta as dificuldades técnicas e econômicas do período em questão, algumas ideias do oficial da Marinha não passaram de desejos não concretizados.

\section{AS MÚLTIPLAS FUNÇÕES DE ITAPURA}

Em 26 de junho de 1858, o então Ministro dos Negócios do Império, Marquês de Olinda (Pedro de Araújo Lima), promulgava o Decreto n²200, que "Crea a Colonia Militar do Itapúra na Provincia de S. Paulo", ${ }^{34}$ juntamente com o seu Regulamento próprio. A Colônia Militar do Itapura fora a única das colônias militares sob direção do Ministério da Marinha - ao invés do Ministério da Guerra - devido a sua função também de estabelecimento naval. Em seu relatório explicitado anteriormente, Mariano - que iria se tornar o primeiro diretor de Itapura - já tinha a intenção de criar algo maior que uma simples colônia militar. Mas também, uma base naval que protegeria o local banhado por dois grandes rios navegáveis em parte (Tietê e Paraná), vias naturais dos produtos produzidos em Mato Grosso, e por serem os únicos acessos, "sítio 
35. Ghiradello (op. cit., p. 3).

36. Atualmente, o Salto do Urubupungá, o Salto do Itapura, o Salto do Avanhandava e as Cachoeiras das Sete Quedas estão todos submersos nas águas das barragens construídas para hidrelétricas no país. Os dois primeiros foram inundados na década de 1960, e os dois últimos na de 1980.

37. Silva (op. cit., p. 19-30).

38. Azevedo (op. cit., p. 22).

39. Cf. Silva (1972). Antonio Mariano assim se referia ao vapor: "Eu trouxe em pedaços um vapor de ferro, que tinha que arma-lo aqui imediatamente em navio de guerra [...] só os profissionais podem imaginar o trabalho que consumia a reunião das peças do casco desse navio, depois de tão longa viagem; a armação e assentamento de sua caldeira; o motor de sua machina, e a promptificação de todos os seus arranjos internos; todos feitos com madeiras tiradas das florestas do Itapura." In: Silva (op. cit., p.23).

40. Barros (1957, p. 292).

41. Ibid., p. 309.

42. Gonzaga da Silva (2017, p. 167-168).

43. Lembrando que há pouquíssimo tempo fora inaugurada a primeira ferrovia brasileira, em 1854, a conhecida Estrada de Ferro Mauá (Imperial Companhia de Navegação a Vapor e Estrada de Ferro de Petrópolis) ligando o porto de Mauá e a cidade de Magé no Rio de Janeiro. estratégico por excelência". ${ }^{35}$ Segundo seu relatório, o local escolhido tinha por fim também aproveitar as 80 léguas de navegação livre que se dispunha entre o Salto do Urubupungá e as Cachoeiras das Sete Quedas. ${ }^{36}$

Silva ${ }^{37}$ esclarece que Itapura apresentou múltiplas funções: militar, naval, agrícola e comunicação (todas já descritas por Mariano em seu relatório), que, na realidade, eram de difícil separação. As funções estavam conectadas umas às outras. O objetivo militar tinha motivos óbvios: proteção. Principalmente "no caso de sermos forçados a uma guerra pela impertinencia de alguns de nossos vizinhos". ${ }^{38}$ Os objetivos navais também já foram tratados acima. Basicamente, era necessário aproximar as relações do litoral com o interior do Império - com a Província de Mato Grosso. Estabelecimento Naval de ltapura deveria ser ponto de sustentação da navegabilidade do Alto Paraná, necessariamente mantendo pequena esquadrilha fluvial.

Itapura, devido a sua importância, recebera o Vapor de guerra Tamandatahy: comprado dos ingleses pelo governo brasileiro, chegou desmontado ao porto de Santos, e carregado, primeiramente por tropas de burros e muares pela serra até São Paulo; e de lá, indo até onde o Tietê se tornava navegável, e a partir de então (ainda desmontado), através da via fluvial até Itapura. ${ }^{39}$ Por fim, um ano após a instalação do estabelecimento naval, era o navio de guerra lançado ao rio, pretendendo-se experimentar suas máquinas, para depois, realizar uma "viagem de exploração minuciosa pelo rio Paraná até o salto de Sete Quedas, ponto mais extremo ao sul que permitia navegação, e bem perto da fronteira com países estrangeiros". ${ }^{40}$ Apesar das inúmeras dificuldades, ali foi montado e, em 1860, fez sua primeira viagem de exploração:

Lançado ao rio em março de 1860, o elegante vapor, de dois rodeirões de ferro laterais e uma chaminé central, vinha prestando serviços à Colônia Militar do Itapura há anos a fio. Fazia, regularmente, uma viagem por mês até o rio Paraná, transportando mercadorias, gado, passageiros, médico e remédios. Era o orgulho daquele pessoal do Itapura. ${ }^{41}$

Outra função do estabelecimento naval era o desenvolvimento da agricultura na região. De acordo com Gonzaga da Silva, ${ }^{42}$ a exploração da terra era um modo de garantir a ocupação e o desenvolvimento do interior. No plano ideal, o objetivo era investir na agricultura, criação de gado e indústria a fim de desenvolver o comércio que seria estabelecido com a bacia do Prata e com a província de Mato Grosso, após o estabelecimento da navegação a vapor, estradas de terra, e até mesmo, posteriormente, ferrovias. ${ }^{43}$ No entorno do seu futuro agrupamento urbano deveria ser promovida a ocupação rural através de pequenas propriedades de terra a serem distribuídas aos colonos-agricultores, que abasteceriam a colônia e, com êxito, suscitariam para a região mais ocupantes. 
Consequentemente, o ideal seria usufruir as vantagens topográficas, climáticas e a situação geopolítica, inicialmente de ltapura, mas que os incentivos transpassassem para Mato Grosso. Os produtos subtropicais dessa província encontrariam mercado certo na Argentina, país que, pela posição geográfica, tinha carência de produtos de clima quente. De acordo com Silva, a partir de 1851, a Argentina passara a ser grande importadora de açúcar, aguardente e café. Assim, em virtude da proximidade de Mato Grosso com esse país, e em razão da fácil navegação para a Bacia do Prata por navios a vapor, haveria mercado vantajoso para ambas as nações. "O planejamento era maravilhoso. Executá-lo, porém, constituía toda a dificuldade. Onde encontrar a mão de obra para tão arrojado plano?"44 $\bigcirc u$ ainda, quanto custaria esse empreendimento? Onde encontrar o capital necessário?

Pensou-se, então, Azevedo, que o Itapura seria a primeira manifestação de desenvolvimento da vasta província mato-grossense, além de se apresentar como sentinela, por onde se infiltraria na província tudo quanto pode concorrer para abrasileirá-la. Porém, sabe-se que o plano de produzir os gêneros de primeira necessidade à colônia, no próprio local, veio a falhar, assim como falharam os demais objetivos da colônia.

Facilitar as comunicações com Mato Grosso era preocupação permanente do governo imperial: ao serem criadas as colônias de Itapura e Avanhandava, nelas se instalou um grupo especial, chamado de estafetas responsável pelo correio entre as duas províncias (São Paulo e Mato Grosso). local escolhido situava-se na rota obrigatória dos estafetas, que conduziam as malas do correio e partindo de São Paulo passavam por Piracicaba, pelo Avanhandava, e daí se dirigiam ao Itapura lpoderiam seguir, posteriormente à Sant'Anna do Parnahyba) e ao Pequiry, com destino a Cuiabá. ${ }^{45}$

Como se vê, ao criar-se o Estabelecimento Naval e Colônia Militar do Itapura, existia completo otimismo em torno dos benefícios que ele traria ao país. Mas os fatos incumbir-se-iam de demonstrar a sua insuficiência, quer como colônia agro-militar, quer como estabelecimento naval, quer como zona postal. 46

\section{O PROJETO URBANO}

Os porquês da escolha do sítio onde se implantaria a Colônia Militar e Estabelecimento Naval do Itapura já foram respondidos anteriormente. Somente para evidenciar: o local escolhido fora no pontal do Tietê-Paraná, no chamado "sertão do
44. Silva (op. cit., p. 28).

45. Cf. Azevedo (op. cit., p. 43-44).

46. Silva (op. cit., p. 30). 
47. A planta foi retirada do processo de tombamento do edifício conhecido popularmente como "Palácio do Imperador" em Itapura. Secretaria de Estado da Cultura: Conselho de Defesa do Patrimônio Histórico, Arqueológico, Artístico e Turístico do Estado - Condephaat. Processo $\mathrm{n}^{\circ}$ 12318/1969. Disponível em: $<$ https://bit.ly/2qyZlwZ>. Acesso em: 21 out. 2019.

48. Brasil (op. cit., p. 378).

49. Utilizando a medida de légua terrestre $=3.000$ braças $=6.000$ varas $=30.000$ palmos, temos o valor métrico de aproximadamente 6.600 metros ou $6,6 \mathrm{~km}$.
Itapura", entre os Saltos de Itapura, Urubupungá e Jupiá, a aproximadamente 13 quilômetros da foz do Tietê no Paraná, à sua margem direita, junto ao Salto do ltapura.

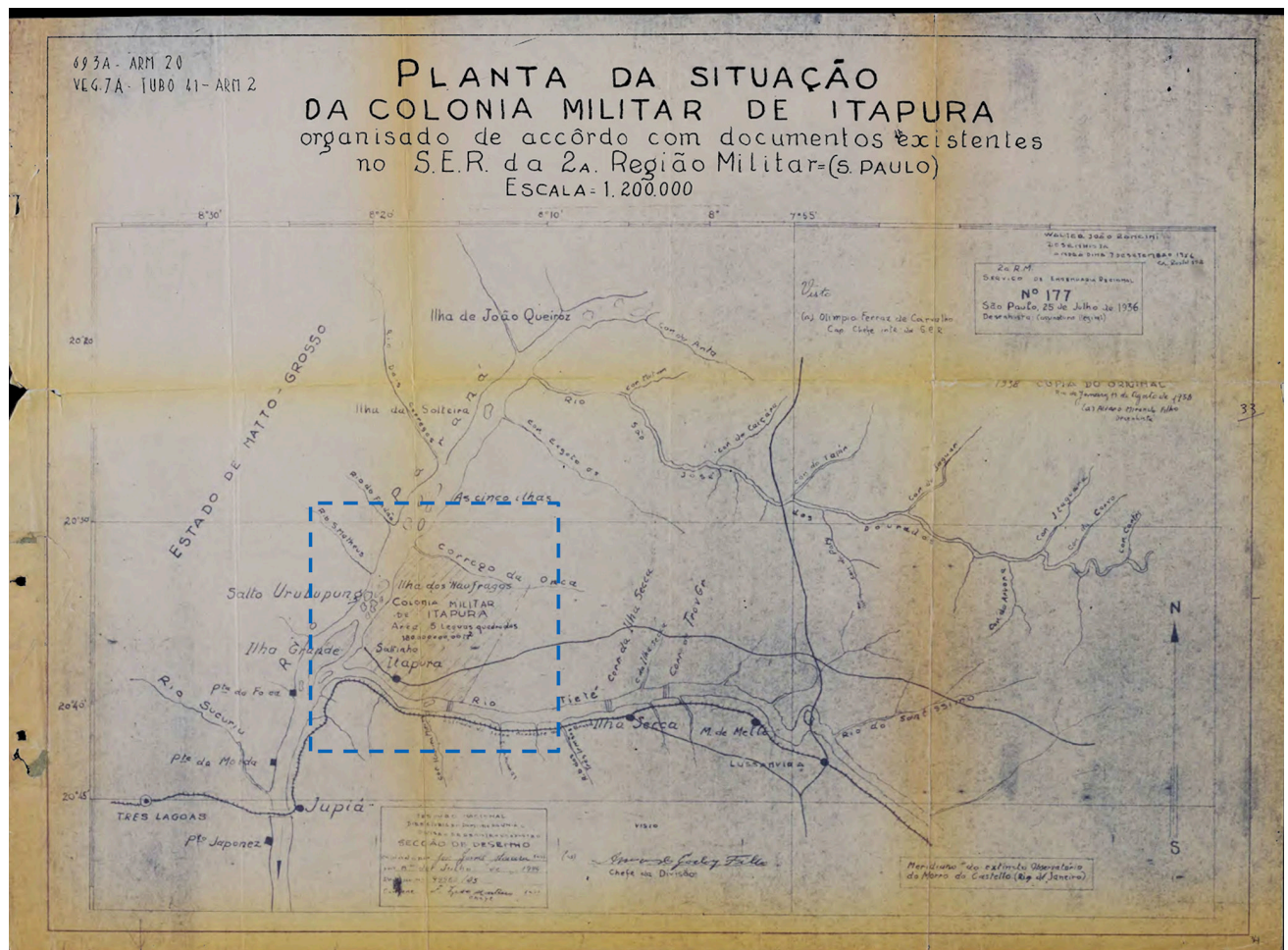

Figura 4 - Planta da situação da colônia militar de ltapura, desenho datado de 1936, constando o antigo traçado da Estrada de Ferro Noroeste do Brasil. Fonte: Secretaria de Estado da Cultura, CONDEPHAAT, Unidade de Preservação do Patrimônio Histórico,, processo n $12318 / 69,47$ editado pelos autores, 2019.

As colônias militares deveriam ser fundadas de preferência em terras devolutas - de acordo com a "Lei de Terras" de 1850. No Regulamento de Itapura, Capítulo I, Art. 1, consta que "O Governo fará medir e demarcar huma legoa quadrada para territorio da Colonia Militar do Itapura, creada por Decreto desta data; e bem assim mais quatro outras contiguas à primeira para districto da mesma Colônia." 48 Assim, pode-se afirmar que a área de ltapura teria cinco léguas quadradas. ${ }^{49}$ As plantas a seguir (figura 4 e 5) ilustram o que foi comentado, delimitando a área da colônia na província de São Paulo.

No mesmo regulamento supracitado, no Capítulo III, Art. 26일 esclarece sobre os colonos: 


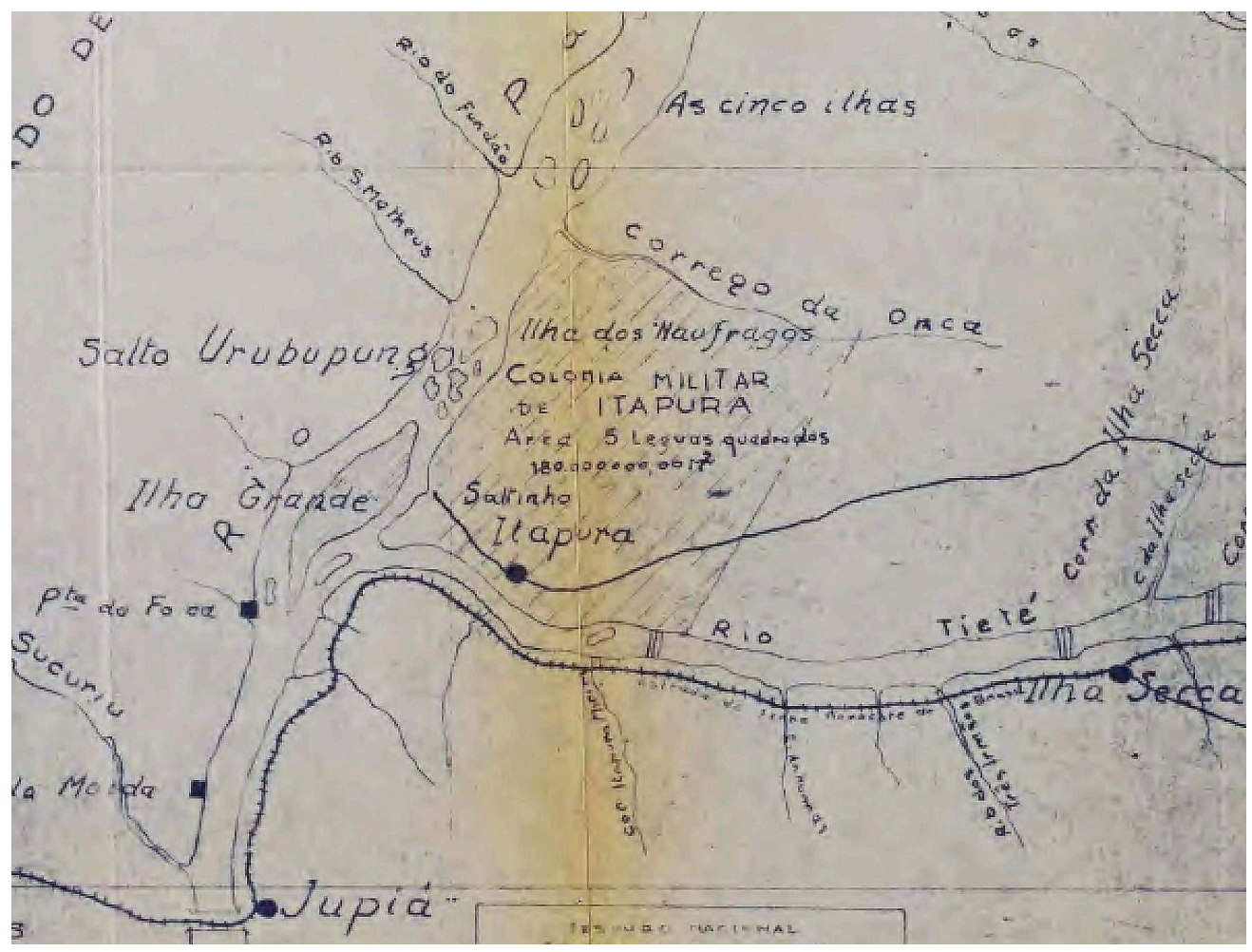

Figura 5 - Detalhe da Planta da situação da colônia militar de Itapura. Fonte: Secretaria de Estado da Cultura, CONDEPHAAT, Unidade de Preservação do Patrimônio Histórico, processo n 12318/69.

Os Colonos serão considerados de quatro classes, pertencendo á $1^{a}$ as praças de pret; á $2^{a}$ os colonos operários; á $3^{a}$ os que por consentimento do Director e approvação do Presidente da Província morarem na Colônia na conformidade do art. $3^{\circ}$ deste regulamento; e á $4^{a}$ os colonos marinheiros e operários navaes contractados. ${ }^{50}$

A título de esclarecimento, o termo "praça de pret" lequivalente ao atual praça de pré, ou mesmo praça) referencia a classe militar que corresponde aos soldados e cabos, principalmente - são aqueles pertencentes à categoria inferior na hierarquia militar, ou seja, não são ainda considerados com a patente de oficial. Dessa maneira, o regulamento estabelecia que a colônia fosse composta de 150 "praças de pret" e suas famílias. Além disso, poderiam ser admitidos até 200 colonos de terceira classe, preferindo aqueles que tenham servido o Exército, fossem casados, ou viúvos com filhos, lavradores e laboriosos. Seriam também considerados os colonos operários necessários para os trabalhos da colônia - aqui o regulamento não estipula números. Os colonos de quarta classe seriam os marinheiros retirados das tripulações, ou operários navais contratados, preferindo os que requererem, e dentre eles os que tiverem família. 
51. Ibid., p. 384

52. Utilizando $2,2 \mathrm{~m}=$ uma braça: colono sem família, lote de 10.000 braças quadradas $=\left(48.400 \mathrm{~m}^{2}\right.$ ou dois alqueires paulistas); colono com família até três pessoas: lote de 22.500 braças quadradas $=108900 \mathrm{~m}^{2}$ ou 4,5 alqueires paulistas; colono com família mais numerosa: lote de 40.000 braças quadradas $=193.600 \mathrm{~m}^{2}$ ou oito alqueires paulistas.

53. Brasil (op. cit., p. 384). Art. 33: "Os colonos da $1^{\mathrm{a}} \mathrm{e}$ $4^{a}$ classes, excepto os operarios navaes contractados, não adquirem o direito de propriedade ao lote de terras, senão quando, tendo sido excusos do serviço, continuarem a residir na Colônia, e beneficiarem a terra por espaço de tres annos, tendo sempre bom comportamento, e meio de vida conhecido." Art. 34: "O colono da $3^{\text {a }}$ classe adquire o direito de propriedade, cultivando o seu lote, e residindo na Colônia por tempo de tres annos a contar do dia, em que deixar de receber as diarias de família, tendo bom comportamento e meio de vida conhecido." Art. 35: "Os colonos da $2^{\text {a }}$ classe e os operarios navaes contractados adquirem direito de propriedade, residindo na Colônia, e cultivando o lote por espaço de tres annos."

54. Cf. Silva (1972, p. 26).

55. Ibid., p. 37.

56. Azevedo (1858, p. 43).

57. Cf. Ghirardello (2006).
Sobre as pequenas propriedades de terra, Cap. III, Art. 320: "A cada hum dos colonos, que requerer, se dará um lote de terras de 10.000 braças quadradas, não tendo família; de 22.500 se tiver família, que não exceda de tres pessoas; e de 40.000 se a tiver mais numerosa." ${ }^{51}$ Ou seja, se fizermos rapidamente um cálculo, descobriremos que os lotes rurais iam aproximadamente de dois a oito alqueires paulistas. ${ }^{52}$ Para o lote de terra ser considerado realmente propriedade do colono, este deveria permanecer trabalhando na colônia por determinado tempo - que era geralmente de três anos, variando de acordo com a classe..$^{53}$ Porém, apesar dos incentivos no regulamento, a situação no ltapura era tal em 1864 que apenas 120.000 braças eram cultivadas de milho, arroz, mandioca e mamona, culturas anuais. A produção agrícola sempre foi irrisória, e a pecuária também não se desenvolvera. ${ }^{54}$

Segundo Silva, ${ }^{55}$ um engenheiro deveria ser encarregado dos trabalhos relacionados à fundação das colônias oficiais. Iria ser o técnico responsável pelo levantamento da planta geral, na qual deveriam constar os lotes medidos e demarcados, o traçado das estradas, pontes projetadas, rios e grandes córregos, e os acidentes geográficos de maior destaque. A urbanização fazia-se indispensável. Azevedo via no planejamento um verdadeiro pré-requisito para o sucesso da colônia, e pretendendo um traçado reticulado, afirmava que "dos actuaes sertões que se vão povoar surja, não uma agglomeração desordenada de casas esdruxulas; mas sim uma cidade edificada sob um plano topographico regular, e moderno". 56

Caso a colônia fosse fundada em bases urbanísticas, pensava ele, decorreria a tendência de atrair não apenas os "praças de pret" e outros militares, ou mesmo oficiais da marinha, mas também os artesãos, colonos civis das regiões mais próximas (como Piracicaba e Sant'Anna do Paranahyba), sem contar, por exemplo, os mineiros, que nesse período migravam para os sertões ribeirinhos do Tietê - e que provavelmente se dedicavam à agricultura e à criação de gado e suínos.

A Colônia Militar de Itapura terá, então, Antônio Mariano de Azevedo como primeiro diretor. É ele quem contará com absoluto apoio do Ministro da Marinha, e define assim o local da colônia: situava-se à margem direita do Rio Tietê, numa área relativamente plana e alta, em uma encosta, constituída de terras ubérrimas. Formidável era a escolha do sítio, garantia a implantação em acrópole, típica das primeiras cidades portuguesas no Brasil, como, por exemplo, Salvador e Porto Seguro, e garantia assim a total visualização do horizonte e do rio. Lembremos que o Rio Tietê era o principal, se não o único, caminho que permitia acesso à colônia, e que, devido ao Salto do ltapura, os barcos precisavam ser retirados da água para varação. Dessa forma, tal posição era estrategicamente interessante, visando à proteção e policiamento daqueles que porventura fossem cruzar o salto. ${ }^{57}$ 
Assim sendo, Azevedo aspirava algo racional, disciplinado, ordenado e regular, próprio da disciplina militar. Outra grande questão era que a colônia deveria ser, de certa forma, a semente de uma futura cidade. O projeto presumido por ele, em quadrícula, estabelecia a configuração:

O plano que adoptei para a povoação é um grande quadrado de 500 braças por lado, composto de 25 outros mais pequenos de 100 braças, separados uns dos outros por meio de ruas de 60 palmos, todas por consequência de 500 de extensão, perpendiculares entre si..$^{58}$

O desenho quadrado e regular almejava algo efetivamente racional, que pudesse transmitir não só ordem e disciplina militar, mas também a presença de "civilização" que vinha para demarcar, proteger e transformar, mesmo que em parte, a paisagem bruta e natural. Tal plano, talvez, possa se aproximar ao castrum romano - acampamentos militares que posteriormente se transformavam em cidades, muitas vezes fundados com o objetivo de ocupação territorial e garantia de domínio, ou apenas para interiorização do povoamento. $\bigcirc$ traçado em xadrez era definido por duas ruas; norte-sul, chamada cardo, e leste-oeste, chamada decumanos. Em seu cruzamento estabelecia-se o forum, onde os soldados se reuniam todos os dias para receber as ordens, e este local tornava-se o centro da futura cidade. Preparavam-se também, posteriormente, a via perimetral, denominada pomerium, muralhas ao redor de todo o acampamento, com quatro portas de acesso, vigiadas por torres que ficavam exatamente nos eixos das duas vias principais. Aos poucos o acampamento recebia calçamento, água encanada, mercados, escolas, anfiteatros, termas, etc. ${ }^{59}$

Além disso, é possível afirmar que o diretor da colônia cumpriu fielmente as indicações da "Lei de Terras" de 1850, que em seu Art. 14, § $1^{\circ}$ diz:

A medição e divisão serão feitas, quando permittirem as circunstancias locaes, por linhas que corrão de norte a sul, conforme o verdadeiro meridiano, e por outras que as cortem em angulosrectos, de maneira que formem lotes ou quadrados de quinhentas braças por lado demarcados convenientemente. .00

Pode-se notar que as dimensões urbanas do projeto de Azevedo batem exatamente com as dimensões indicadas pela passagem supracitada. Apesar de que, na lei, a indicação seja para o módulo rural. Nesse caso, se torna assim, talvez devido à pequena extensão da colônia, congruente com sua zona urbana. Além disso, "os quarteirões eram divididos em lotes de 10 braças ou 22m de frente, por 50 braças ou $110 \mathrm{~m}$ de fundo, destinados à casa dos colonos e respectivo quintal". ${ }^{61}$ A partir desta citação percebe-se que, novamente, Mariano se apoia
58. Silva (op. cit., p. 38).

59. Cf. Macaulay (1989); Mumford (1982).

60. Brasil (1850, p. 307).

61. Silva (op. cit., p. 40). 
62. Brasil (1854, p. 23).

63. Silva (op. cit., p. 40).

64. Benevolo (2019, p. 128).

65. Ghirardello (op. cit., p. 8). em leis estabelecidas até então, como é o caso do Art.77, pertencente ao já citado Decreto $n^{\circ} 1318$, que regulamentava a Lei de Terras, em 1854 :

As terras reservadas para fundação das Povoações serão divididas, conforme o Governo julgar conveniente, em lotes urbanos e ruraes, ou somente nos primeiros. Estes não serão maiores de 10 braças de frente e 50 de fundo. Os ruraes podem ser de maior extensão, segundo as circunstancias o exigirem, não excedendo porem cada lote de 400 braças de frente sobre outras tantas de fundo. ${ }^{62}$

Ainda sobre a descrição dos lotes da colônia:

Esses lotes forão distribuídos aos colonos para caza e quintal e em quase todos elles há com effeito um rancho barreado mais ou menos bem feito, e quintal com hortas, aves, porcos, cabritos, carneiros, vaccas de leite. Os quintaes são separados entre si, e das ruas, por cercas de arueira rachadas e solidamente enterradas. A frente das cazas mesmo está 20 palmos para dentro dessas cercas, de sorte que ao passo que a área das ruas é marcada em alinhamento perfeitamente regular, o pequeno affastamento em que dellas se achão as habitações formão em suas frentes pateos, que dão a seos moradores recreio e independencia. ${ }^{63}$

Nesse período, o diretor da colônia decerto saberia que a regularidade urbana estava cada vez mais presente nas cidades brasileiras - principalmente em núcleos novos, em áreas pioneiras, o denominando sistema "regular e moderno". De qualquer maneira, iá presente desde os gregos, conforme Benevolo, com Hipódamo de Mileto considerado o "inventor da divisão regular da cidade", ${ }^{4}$ aplicando a geometria ao traçado urbano. A simplicidade da implantação de uma malha em xadrez facilitava, então, a demarcação do traçado, era expansível, com quadras e lotes previsíveis, além de tornar os processos de compra, venda, ou transmissão, rápidos e acessíveis. Regras simples, abrangentes, e gerais; imposição essencial do capitalismo cada vez mais em vigor. ${ }^{65}$

Abaixo (figura 6) busca-se, de uma maneira simples, porém ilustrativa, demonstrar a espacialidade exposta através do plano de Mariano de Azevedo:

A figura 6 representa a quadrícula de $500 \times 500$ braças $(1.100 \times 1.100$ metros) imaginada por Mariano de Azevedo, com seus 25 quadrados menores, medindo $100 \times 100$ braças cada (220 × 220 metros), margeados pelas ruas de 60 palmos (13,2 metros) perpendiculares entre as intersecções. A rigor, a colônia era formada por uma área urbana regular, como mostrado no desenho acima; e outra área rural - que seria parcelada em propriedades para os colonos. domínio do território pretendido pelo diretor, e pela colonização militar de modo geral, seria exercido através do controle do espaço urbano e rural. 


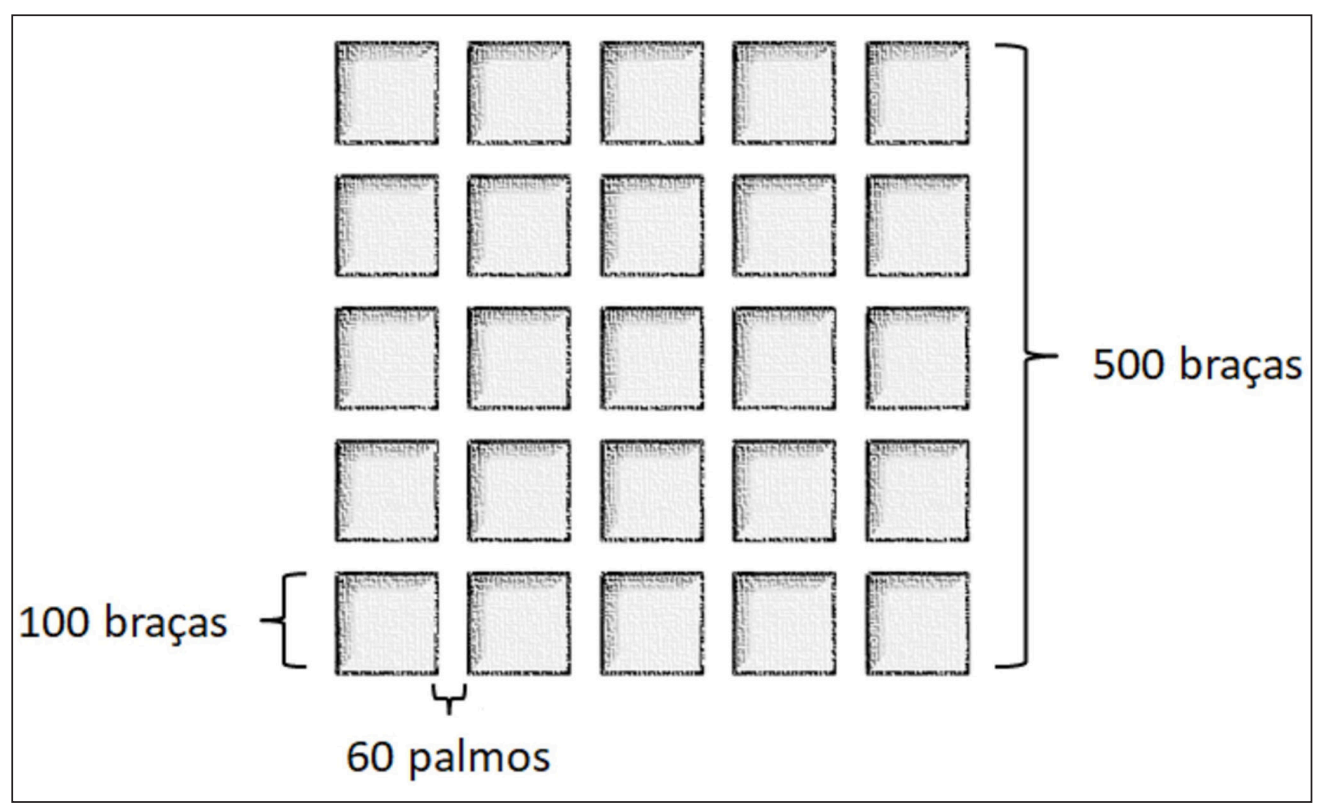

Figura 6 - Croqui representando o projeto de Antonio Mariano de Azevedo para a Colônia Militar do Itapura. Fonte: elaboração própria, 2019, sem escala.

Muito provavelmente o projeto ideal de Azevedo tenha experimentado adaptações em sua implantação no sítio. Concluir-se-á adiante que sua dimensão será bem menor do que a prevista em função do número reduzido de habitantes, o perímetro será menos preciso, e outros elementos surgirão, como praças e espaços públicos, por exemplo. Contudo, entre o ideal e o possível, o plano foi transformado em função do terreno. Estradas que se dirigiam às áreas rurais circundantes, caminhos e pontes também eram realizados nas cidades militares romanas onde a regularidade da grade era interrompida por algumas curvas.

\section{A ARQUITETURA}

Cabe-nos aqui considerar os levantamentos alcançados a respeito das quatro plantas coletadas. As duas primeiras plantas pertencem ao século XIX, e as outras duas ao século XX. Primeiramente serão analisadas as plantas elaboradas enquanto a colônia militar ainda estava em plena função, apesar das dificuldades. $\bigcirc$ primeiro documento, cronologicamente, é de junho de 1878, denominado Planta da Colônia Militar de Itapura (figura 7), elaborada 
por Carlos Frederico de Lima, tenente-coronel do corpo de engenheiros. $O$ original se encontra na Biblioteca Nacional (RJ), acervo cartográfico.

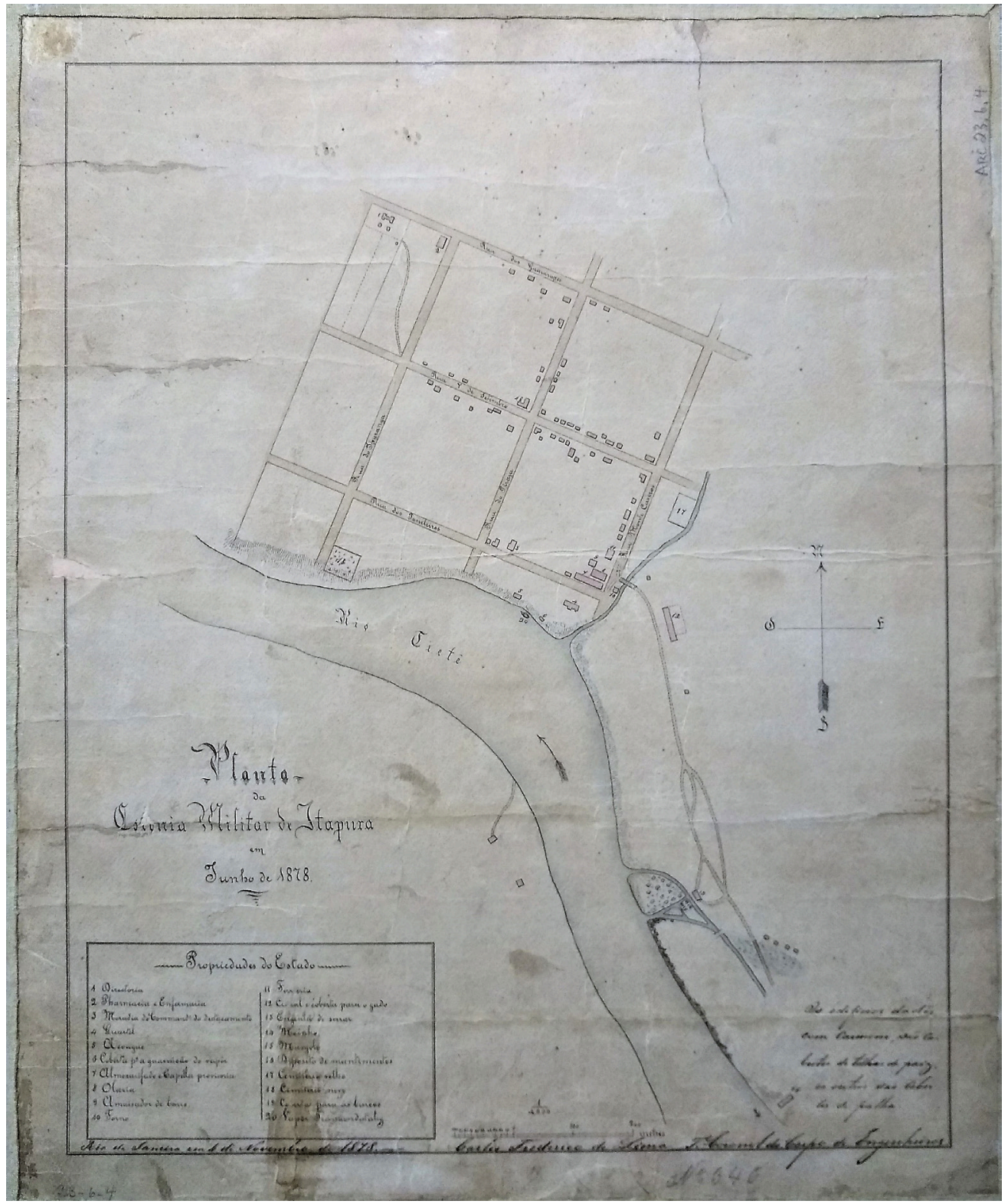

Figura 7 - Planta da Colônia Militar de Itapura, jun. 1878, Carlos Frederico de Lima. Fonte: Acervo da Fundação Biblioteca Nacional do Rio de Janeiro. Fotografia dos autores, 2018.

A segunda planta (figura 8) foi elaborada por Ercole Giannelli em 1885, denominada Província de S. Paulo: Colônia Militar de Itapura, cujo original está, igualmente, no acervo cartográfico da Biblioteca Nacional do Rio de Janeiro. 


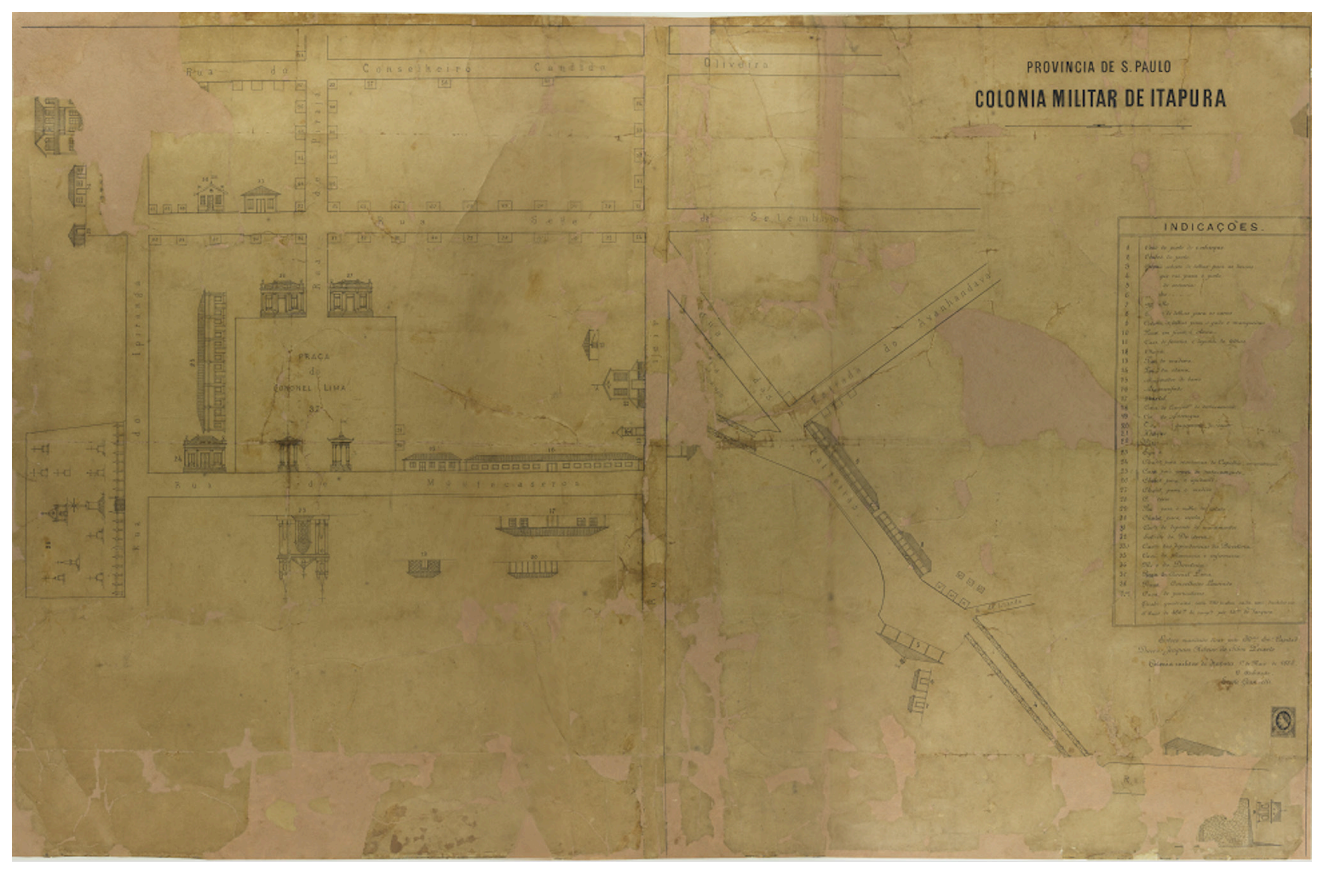

Figura 8 - Colônia Militar de Itapura, 1885, Ercole Giannelli. Fonte: Acervo do Arquivo Histórico do Exército, Rio de Janeiro.

A partir disso, podemos constatar algumas diferenças. A planta de Giannelli (figura 8) talvez seja a que mais se distancia, entre as quatro plantas, do plano descrito por Azevedo. Apesar de o traçado ser representado, o que mais se destaca no desenho são as construções de maior importância e os detalhes de suas fachadas. Destaque para a praça maior (chamada Coronel Lima) à esquerda, com a igreja, os coretos, e outros edifícios "públicos" com suas fachadas rebatidas ao redor. Representando assim lugar de grande importância simbólica na colônia, explicitamente religioso, mas também cívico-militar. Religioso por ser, possivelmente, exemplo de adro, extensão da igreja que, lembremos, representava também o governo como braço do império. Sua construção colocava o poder deste nos locais mais afastados. Cívico por ser um notável espaço de convívio, uma possível praça de comércio e de reunião dos futuros habitantes em momentos festivos. Militar por ser uma parte solene do traçado, onde as tropas de colonos-soldados se agrupariam para a marcha, organização de atividades de defesa, vigília e outros hábitos militares.

Grande diferença a se notar é que as quadras, na planta de Giannelli, não são representadas como quadrículas exatas - apresentam-se, portanto, com dimensões irregulares. Além disso, aparece à direita uma "Estrada do Avanhandava" - provavelmente era a estrada que se destinava ao Salto do Avanhandava. A rua 
que se dirige ao porto (em diagonal) existe em ambas, com a diferença de que Giannelli a representa de forma mais retilínea em sua planta, em que está denominada "Rua das Paineiras", enquanto no desenho anterior não consta tal nomeação. Outro aspecto que chama a atenção é a posição da casa do diretor: na planta de Giannelli ela se encontra próxima ao tecido urbano; já no desenho elaborado por Lima lfigura 7), a posição é mais acima, distante do conjunto urbano.

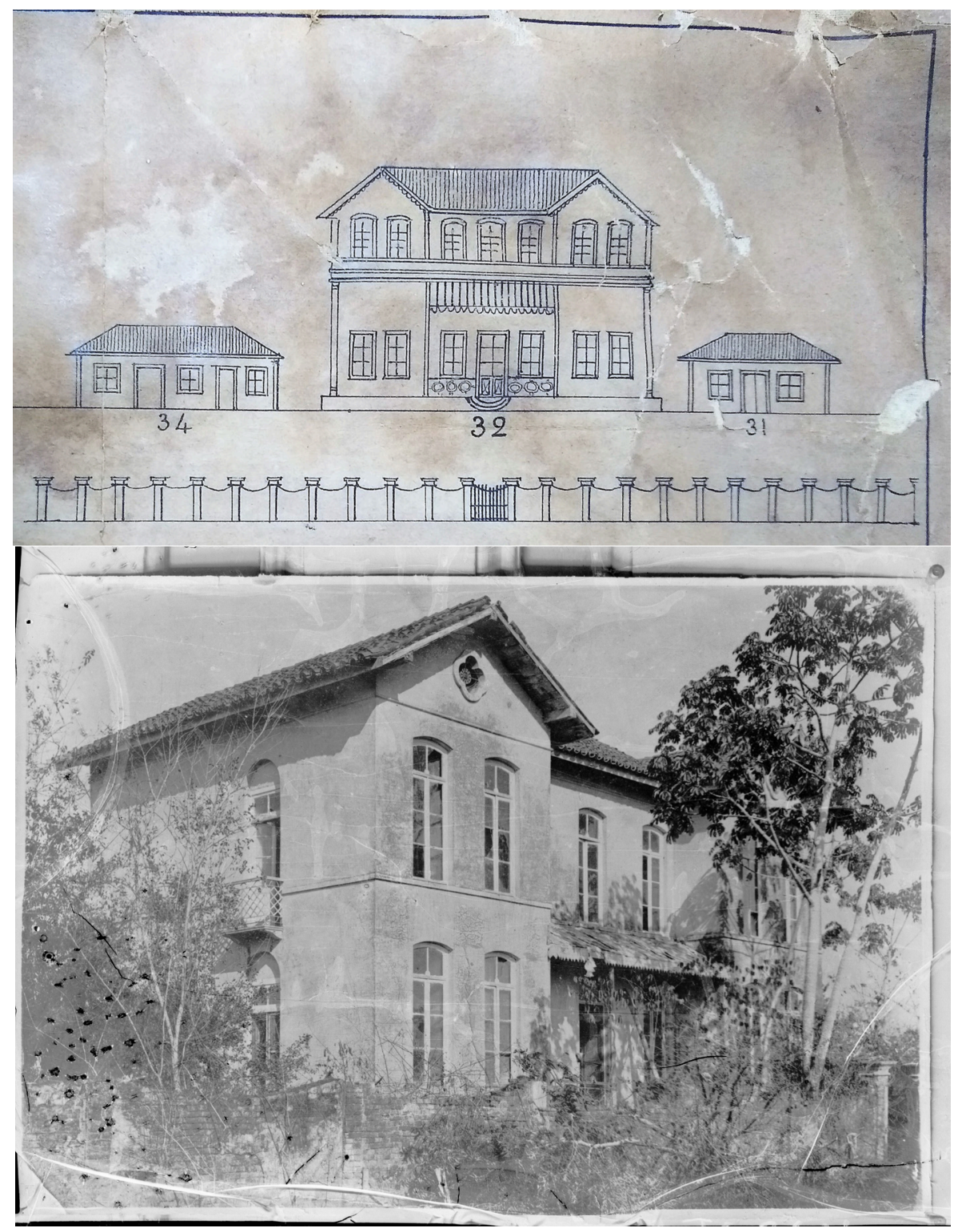

Figura 9a - No alto, casa do diretor, detalhe da Planta da Colônia Militar de Itapura, 1885. Fonte: Acervo da Fundação Biblioteca Nacional do Rio de Janeiro. Figura 9b - Acima, casa do diretor, c. 1905. Fonte: Acervo do Museu Paulista (IC: 1-036 1 1-0000-0000). Foto: Helio Nobre/José Rosael. 


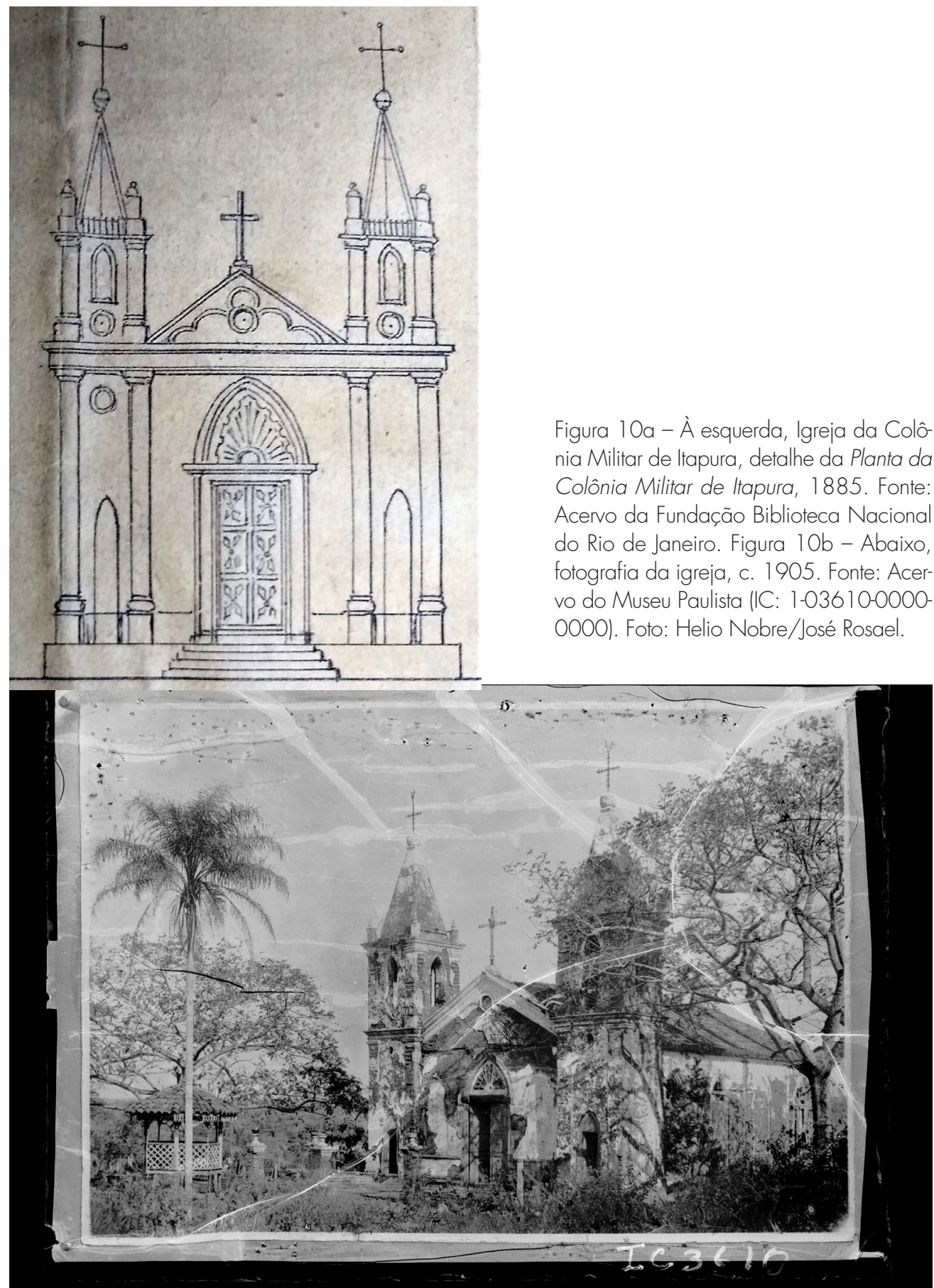

Entretanto, temos que considerar que Giannelli foi notadamente fiel em relação às fachadas das edificações, pois, ao comparar com as fotografias feitas pela CGGSP (ver composições de figuras adiante) das ruínas da colônia nos anos 1905 aproximadamente, vê-se que são semelhantes. Assim, resta-nos considerar 
que a planta de Giannelli talvez seja mais esquemática do que real, ou seja, como o desenho não apresenta escala gráfica ou numérica, não havia comprometimento com a proporção dimensional do desenho, com o tamanho das vias, e mesmo com a posição exata das edificações nas quadras. Porém, e aqui temos como comprovar pelas fotografias adiante, é um levantamento muito rico a respeito das edificações existentes em 1885 na Colônia Militar de Itapura, do mesmo modo sobre sua tipologia arquitetônica. A seguir algumas comparações:

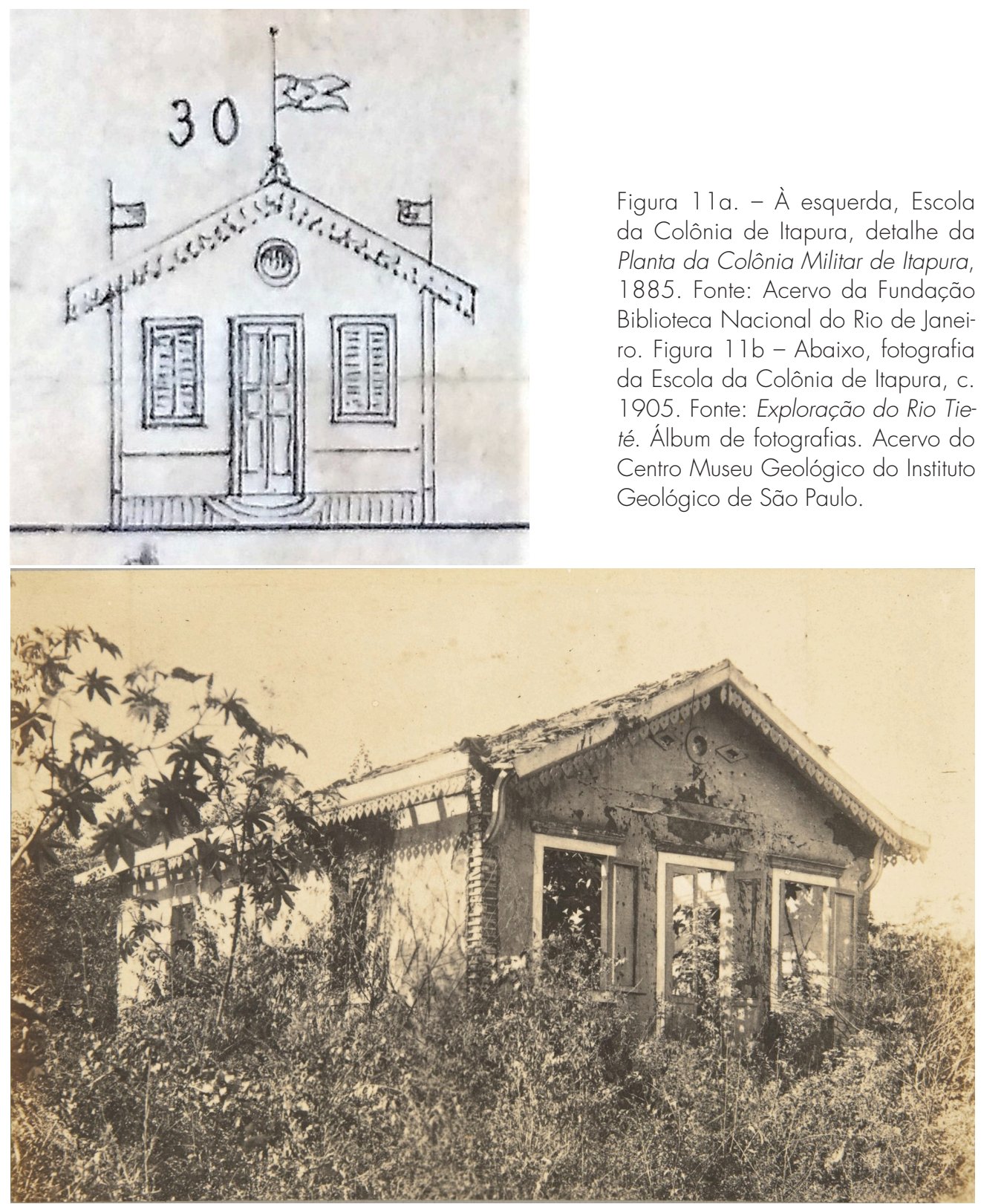




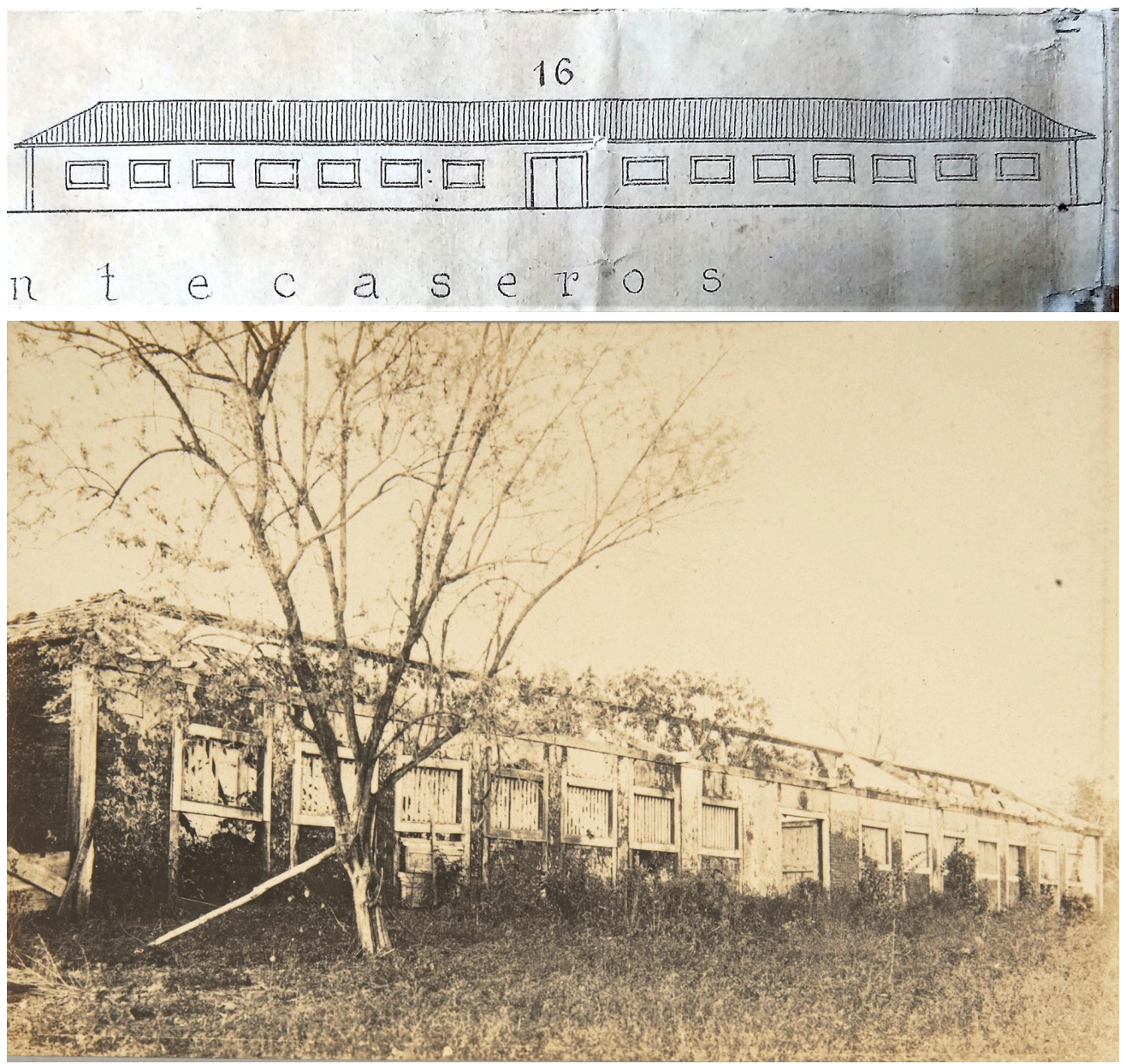

Figura 12a - No alto, almoxarifado, detalhe da Planta da Colônia Militar de Itapura, 1885. Fonte: Acervo da Fundação Biblioteca Nacional do Rio de Janeiro. Figura 12 b - Acima, fotografia do almoxarifado, c. 1905. Fonte: Exploração do Rio Tieté. Álbum de fotografias. Acervo do Centro Museu Geológico do Instituto Geológico de São Paulo.

Ao observar atentamente, percebe-se, com as figuras lado a lado, as semelhanças existentes entre as elevações desenhadas por Giannelli em sua planta e as fotografias das ruínas de Itapura, captadas pela equipe da CGGSP. Uma semelhança entre as duas plantas analisadas é a extensão da colônia, representada bem menor do que proposto por Azevedo (exemplificado no croqui, figura 6, 500 $\times 500$ braças - ou cinco por cinco quadras), contendo menos do que o planejado. Pode-se supor, então, que o tamanho representado seja devido ao não crescimento da colônia como se imaginava. Possivelmente, tenha sido essa a razão da casa do diretor ter ficado isolada, em ponto mais alto, quando deveria estar inserida na malha urbana, porque esta não se expandiu o bastante para "alcançá-la". 

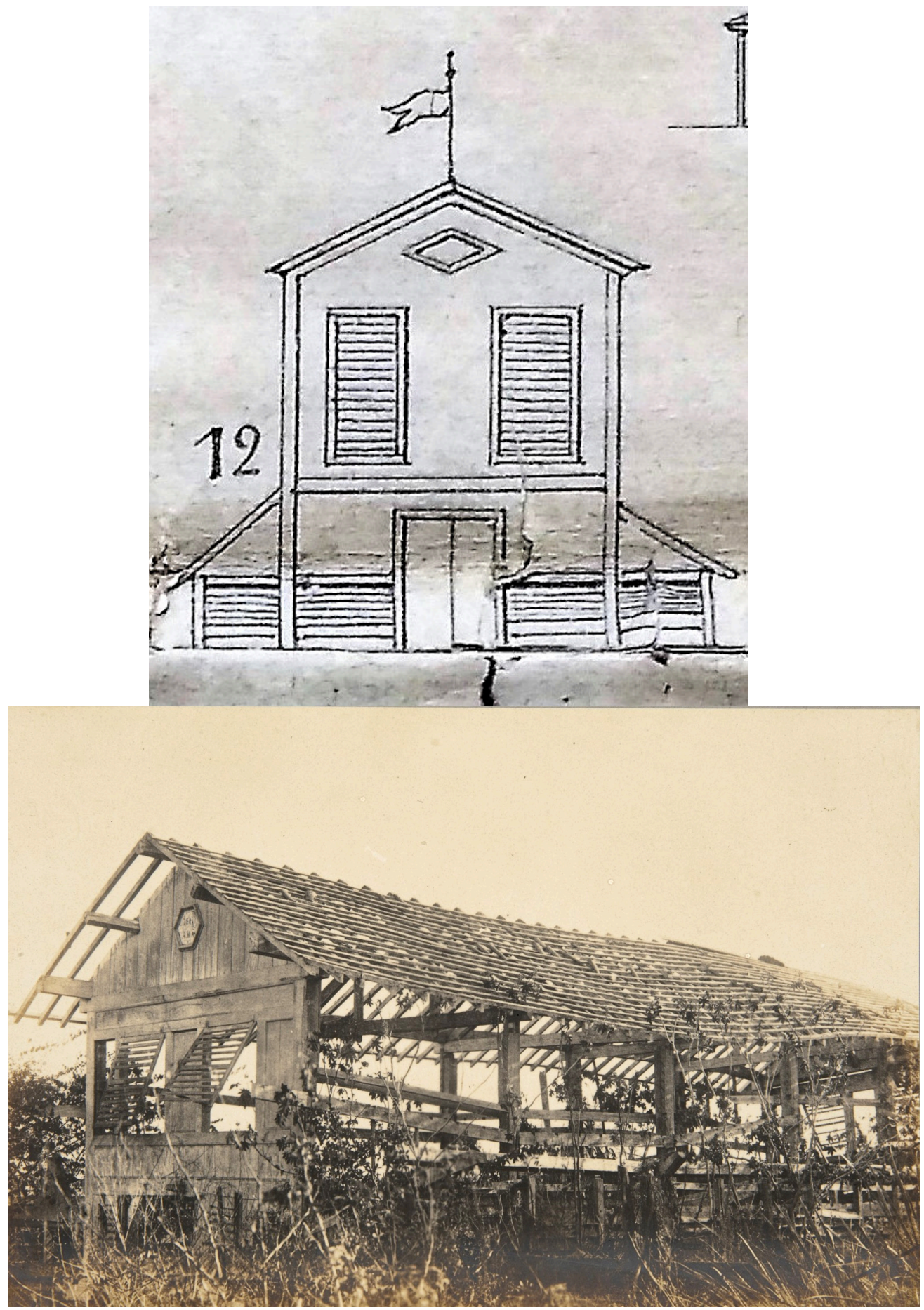

Figura 13a. - No alto, olaria, detalhe da Planta da Colônia Militar de Itapura, 1885. Fonte: Acervo da Fundação Biblioteca Nacional do Rio de Janeiro. Figura 13 b - Acima, fotografia da olaria, c. 1905. Fonte: Exploração do Rio Tieté. Álbum de fotografias. Acervo do Centro Museu Geológico do Instituto Geológico de São Paulo. 


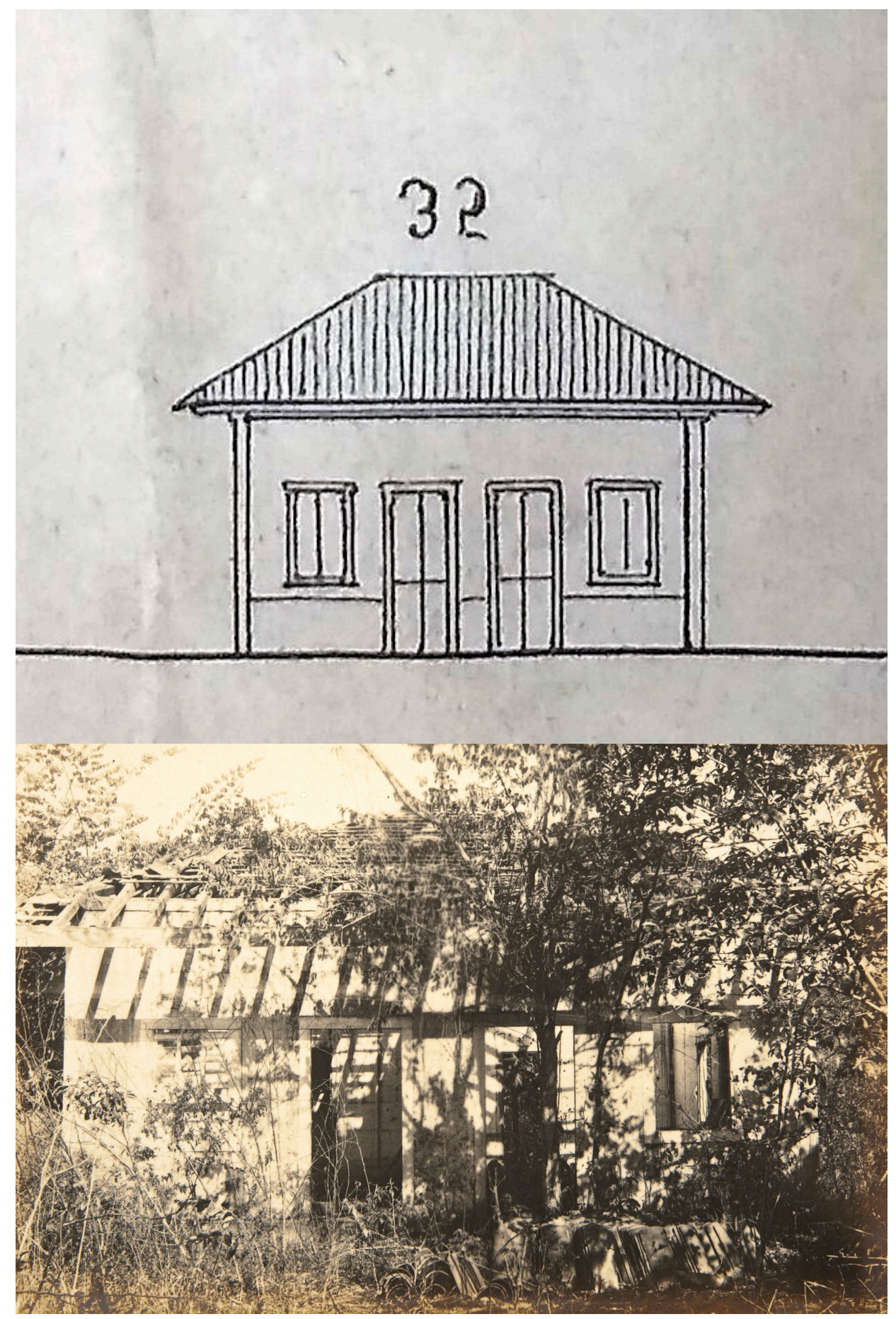

Figura 14a - No alto, casa da pharmacia e enfermaria, detalhe da Planta da Colônia Militar de Itapura, 1885. Fonte: Acervo da Fundação Biblioteca Nacional do Rio de Janeiro. Figura 14bAcima, fotografia da farmácia e enfermaria, c. 1905. Fonte: Exploração do Rio Tieté. Álbum de fotografias. Acervo do Centro Museu Geológico do Instituto Geológico de São Paulo. 
66. Silva (op. cit., 43-54).

67. Ibid., p. 45.

68. Em 1858, quando a Lei Orçamentária do Império previa a soma de 200:000\$000 para todo o sistema de presídios e colônias militares, só o Itapura gastara 179:966\$543. No período 1859-60, a quantia calculada foi de 106:153\$012. Silva (1972 p. 58).

69. Silva (1972, p. 45).

70. Ibid., p. 46.
Segundo Silva, ${ }^{66}$ cerca de 192 pessoas compunham a população inicial. Tudo ali precisava ser feito. A presença do "africano livre" logo se fez sentir. Foi ele quem desflorestou as matas para a demarcação do centro da colônia, suas picadas e seus arredores. Ao lado da floresta apareciam os cerrados e cerradões. No início, as condições de vida foram extremamente difíceis. Os futuros moradores se abrigavam em barracadas de algodão trazidas na viagem, assim como nos acampamentos romanos. A seguir, ainda em caráter provisório, surgem os primeiros ranchos, ou ranchões, principalmente para abrigar os materiais da marinha. Após isso, são construídas as "palhoças" - para abrigar os colonos. Os materiais utilizados para as primeiras construções eram obtidos in loco, como areia, pedras, "madeiras de lei" (como cedro, aroeira, peroba, ipê, cabreúva), "Entretanto, a improvisação teve caráter efêmero, o que destacou o Itapura das demais colônias militares, nas quais as choças e barrotes adquiriam características definitivas." "67 Itapura podia ser considerada uma colônia especial no recebimento de recursos. As verbas eram realmente vultosas, segundo Silva. Pelos orçamentos dos anos 1859 e 1863, nota-se que os gastos efetuados pelo Ministério da Marinha com Itapura eram muito superiores aos demais, sendo assim considerada como um dos mais dispendiosos estabelecimentos do segundo reinado. ${ }^{68}$

A evolução fazia-se de maneira gradativa. No começo, as construções foram precárias, contudo, diferentemente das outras colônias que permaneceram nesse estado precário, Itapura foi substituindo suas palhoças por obras arquitetônicas de qualidade significativa para a época. Logo foi instalada uma olaria (ver figura 13), com dois pavimentos: no inferior fabricavam-se telhas, e na parte superior, tijolos. Estes tinham tamanho excepcional - com 3,9 kg, $27 \mathrm{~cm}$ de comprimento e $7 \mathrm{~cm}$ de altura. Chegou-se a fabricar até 4.000 telhas numa única fornada. De fora vinham ferro, vidro e cal, geralmente trazidos de Piracicaba. ${ }^{69}$

Ao passo que na maioria das colônias erguia-se de início a igreja, as primeiras construções erguidas em Itapura foram a casa de desenho e risco, em seguida uma oficina de serralheiro e outra de ferreiro, além do almoxarifado (ver figura 12). Ou seja, isso demonstra o sentido lógico e o plano construtivo que guiava as ideias de Azevedo, o qual procura erguer, portanto, as construções que subsidiam e fornecem os elementos básicos - desenhos técnicos e materiais de construção basicamente, dando fundamento para edificar sua colônia.

Em 1862, após a aclimatação dos colonos, foi um período propício para o desenvolvimento urbano do estabelecimento. Neste ano construiu-se uma enfermaria, com alojamento para o médico e o boticário. Depois foi construído o quartel de pedra e tijolos, "tão sólido que, à exceção do da capital, não havia outro [como ele] na província de São Paulo"70 Ergueu-se também nesse ano a prisão, com dois 
compartimentos, um para cada sexo; possuía tarimbas ${ }^{71}$ e janelas gradeadas de ferro. Após isso, a residência dos soldados casados, e a do comandante do destacamento militar. Movidos a água, eram as casas de serraria, o monjolo e o moinho de fubá, além de abastecer posteriormente, por encanamento, toda a colônia. ${ }^{72}$

$\bigcirc$ estabelecimento chegou a possuir 90 edifícios de alvenaria, logo, era certamente mais organizado que muitas cidades do império. ${ }^{73}$ As construções de realce eram a escola, a enfermaria, a igreja, o cemitério, a prisão, o quartel, e a casa do diretor. A igreja (figura 10), segundo Barros, ${ }^{74}$ foi iniciada no ano de 1878, construída em tijolos, com esteios e baldrames de aroeira lavrada, e que ainda se achava em pé em 1905, quando no ltapura esteve a comissão exploratória do Rio Tietê, chefiada pelo Dr. Jorge Black Scorrar. A base do templo achava-se em seguros alicerces de pedra e cal. As paredes de tijolos mediam $46 \mathrm{~cm}$ de espessura e $5 \mathrm{~m}$ de altura. A nave tinha $22 \mathrm{~m}$ de fundo por $8 \mathrm{~m}$ de frente. Na fachada, havia duas torres laterais de planta quadrada e cúpulas piramidais, o frontão era neoclássico dotado de óculo central, terminados por cruzes de ferro lao todo eram três - duas nas torres e uma ao centro), e o vigamento era todo em peroba e sucupira. Possuía uma porta principal, dez janelas laterais, em arcos ogivais - já representando o gosto eclético e neogótico - e mais duas na frente e duas no fundo; além de dois coretos de madeira treliçada e com planta sextavada, que ficavam à sua frente. ${ }^{75}$

Outra construção importante, embora pequena e muito bela, era a Capela da Piedade, também de estilo neoclássico. "Sua fachada se remetia a um Arco do Triunfo romano com portada em arco pleno e magnífico dintel, tendo ao lado pilastras jônicas, frisos e arrematando o conjunto, elaborada arquitrave"76 (ver figura 15, a seguir). $\bigcirc$ "chalet" da escola também merece destaque (ver figura 11), dotada de telhado em duas águas, beirais com esmerados lambrequins de madeira rendilhada, muito provavelmente montados em Itapura, comprovando a qualidade artesanal da serraria e marcenaria local - não era somente o chalet da escola que apresentava lambrequins de madeira.

Contudo, o edifício que ostentava maior elegância era a casa do diretor (ver figura 91, a única construção que ainda existe e resiste até hoje, tombada pelo Condephaat em 1969, situada em cota mais elevada dentro do traçado urbano. Um amplo edifício, em planta " $\mathrm{H}^{\prime}$, com dois pavimentos, construído em tijolos e com todos os cômodos forrados e assoalhados, alguns até elegantemente dotados de pinturas e murais pintados e forrados de papel francês. Com janelas de vidro e sacadas-balcão nas laterais com grades de ferro. "No tímpano dos frontões, óculos em quadrilóbulo, de nítida influência neogótica, telhas em capa e canal, beirais de madeira, onde primitivamente deveria haver lambrequins." 77 Exibia em sua fachada sete portas no piso inferior, e sete janelas no superior, com bandeiras em arco abatido.
71. Tarimbas: estrados de madeira, planos e duros, onde dormiam os soldados nos quartéis e postos de guarda.

72. De acordo com Silva (1972, p. 47), o encanamento media $242 \mathrm{~m}$ de extensão, com objetivo de a água alimentar a serraria e o moinho, e posteriormente abasteceu toda a colônia.

73. Cf. Silva (op. cit.); Ghirardello (2006).

74. Cf. Barros (1957).

75. Cf. Barros (1957); Ghirardello (2006).

76. Ghirardello (op. cit., p. 12).

77. Ibid. 


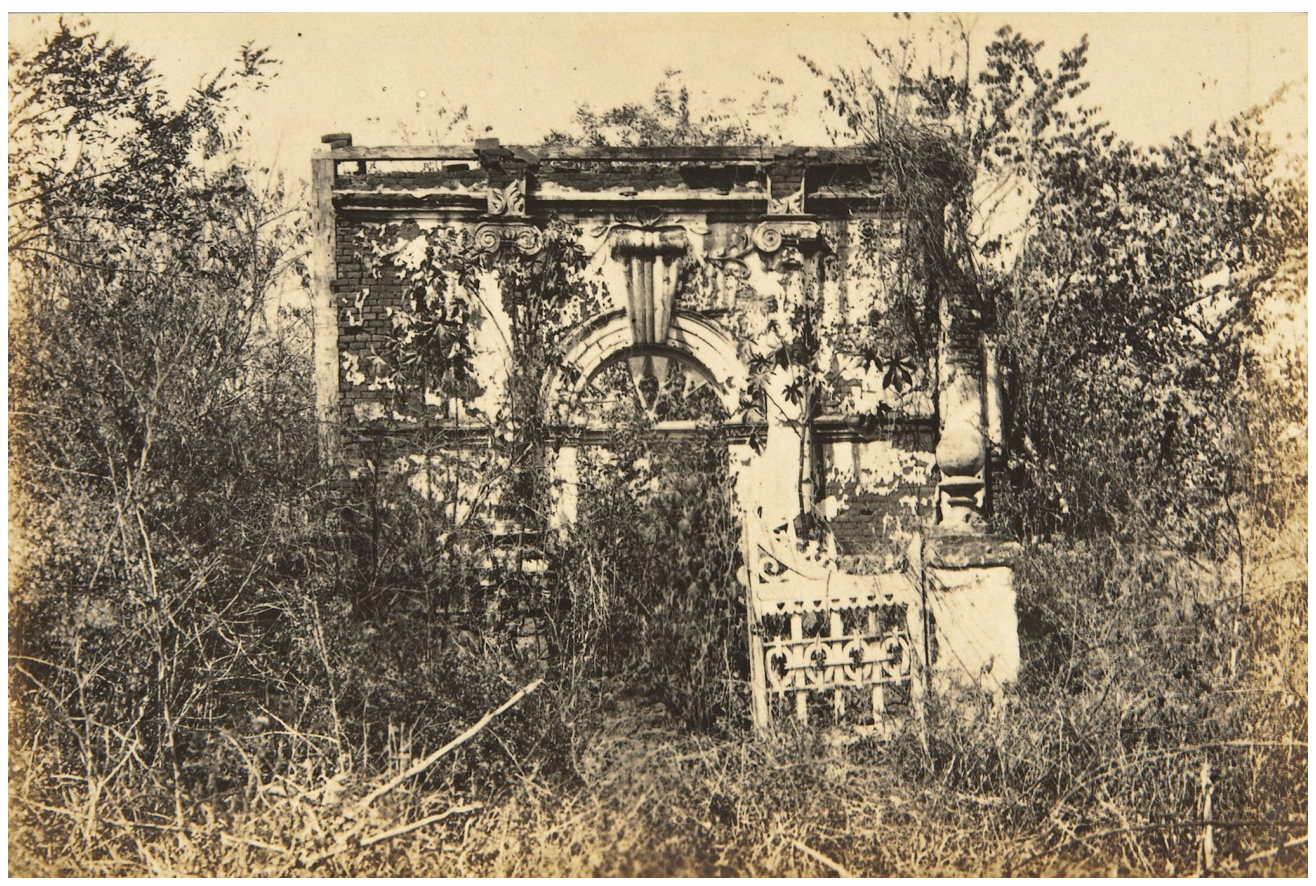

Figura 15 - Capela da Piedade, em rúnas. Colônia Militar de Itapura, c. 1905. Fonte: Exploração do Rio Tieté. Álbum de fotografias. Acervo do Centro Museu Geológico do Instituto Geológico de São Paulo.

Ao voltar-se para a configuração espacial, expressa na planta de Lima (figura 7), percebe-se que havia três ruas paralelas ao Rio Tietê: Toneleiros, Sete de Setembro e Guararapes (há certa diferença entre os desenhos, por exemplo, na planta de Giannelli, a rua que antes era denominada Toneleiros aparece agora como Montecaseros). Também há as ruas perpendiculares, na planta de Lima: Ipiranga, que ligava a Praça da Diretoria ao cemitério, arborizada com cajás; Pirajá e Montecaseros. Apesar do suposto equívoco de Giannelli ou Lima ao mesclarem os nomes das ruas, ou o fato destas realmente trocarem de denominação; o que realmente importa é que havia uma preocupação com o traçado harmonioso.

Numa demonstração de cuidado com as técnicas urbanísticas, havia três praças: Coronel Lima (provavelmente em homenagem ao engenheiro, tenente-coronel que elaborou a primeira planta de 1878), a da Diretoria e a do Conselheiro Laurindo - que só aparecem assim denominadas na planta de Giannelli. A praça principal era a Coronel Lima, centralizada, e que possuía a lgreja Matriz regendo o espaço, ao seu redor os coretos, e as duas construções ecléticas na face oposta lque, segundo a legenda, eram os "chalets" do ajudante e do médico). Espaço nobre e central por 
excelência, onde provavelmente deveriam acontecer as solenidades oficiais e ser o local onde os soldados perfilavam para serem passados em revista.

Havia também a Rua das Paineiras, que seguida por uma ponte, ligava ao cais do porto, cavado na própria rocha. Existia ainda, em frente à olaria, outra ponte, que, sendo a entrada principal à cidadela, era guardada por torres de madeira. De acordo com Silva, ${ }^{78}$ as ruas eram calçadas com paralelepípedos e arborizadas com paineiras, palmeiras e cajazeiras, mostrando o cuidado com o paisagismo.

As espécies, é bom frisar-se, vinham da flora brasileira o que não era comum, pois as espécies estrangeiras eram as mais valorizadas. O uso do jerivá, ainda, é algo surpreendente, pois vinha da mata de cerrado da região da colônia e substituiu a exótica Palmeira Imperial, na criação de renques junto às ruas. $\bigcirc$ símbolo paisagístico maior da aristocracia do Império é trocado em favor de outra espécie menos nobre, mas nem por isso menos bela. ${ }^{79}$

† terceiro documento/mapa coletado, referente à planta da colônia militar de Itapura, é datado do início do século XX (neste período a colônia já havia sido desativada). Encontra-se em um dos mapas anexos ao Relatório de "Exploração do Rio Tietê (Barra do Rio Jacaré-Guassú ao Rio Paraná)", realizado pela Comissão Geográfica e Geológica do Estado de São Paulo (CGGSP) no ano de 1905 - sob a direção de João Pedro Cardoso, e também chefiada por Jorge Black Scorrar. $\bigcirc$ levantamento mostra em detalhes precisos o Pontal do Rio Tietê: o deságue das águas do Rio Tietê no Rio Paraná; o Salto do Itapura e seus arredores (planta da ex-colônia militar), a llha Grande, o Salto do Urubupungá, as seções transversais de cada um dos rios, sua profundidade, dimensões até as margens, e outras informações, como se vê na figura 16.

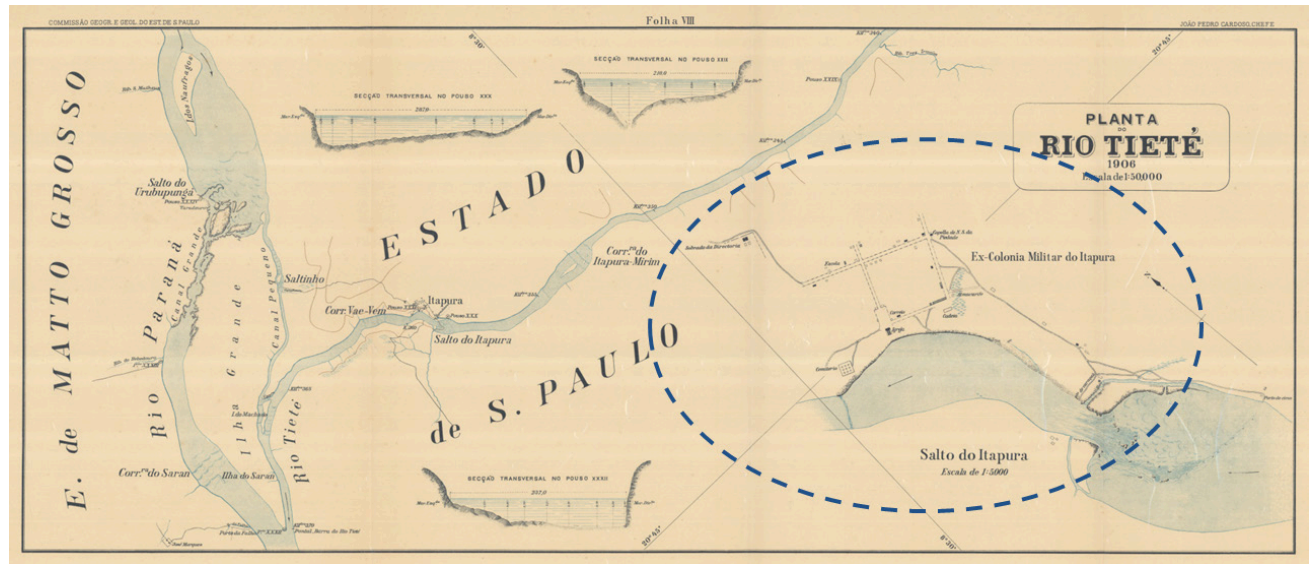

Figura 16 - Planta do Rio Tietê, 1906. Fonte: Exploração do Rio Tieté. Acervo do Centro Museu Geológico do Instituto Geológico de São Paulo, folha VIII, editado pelos autores.
78. Cf. Silva (op. cit.).

79. Ghirardello (op. cit., p. 13). 


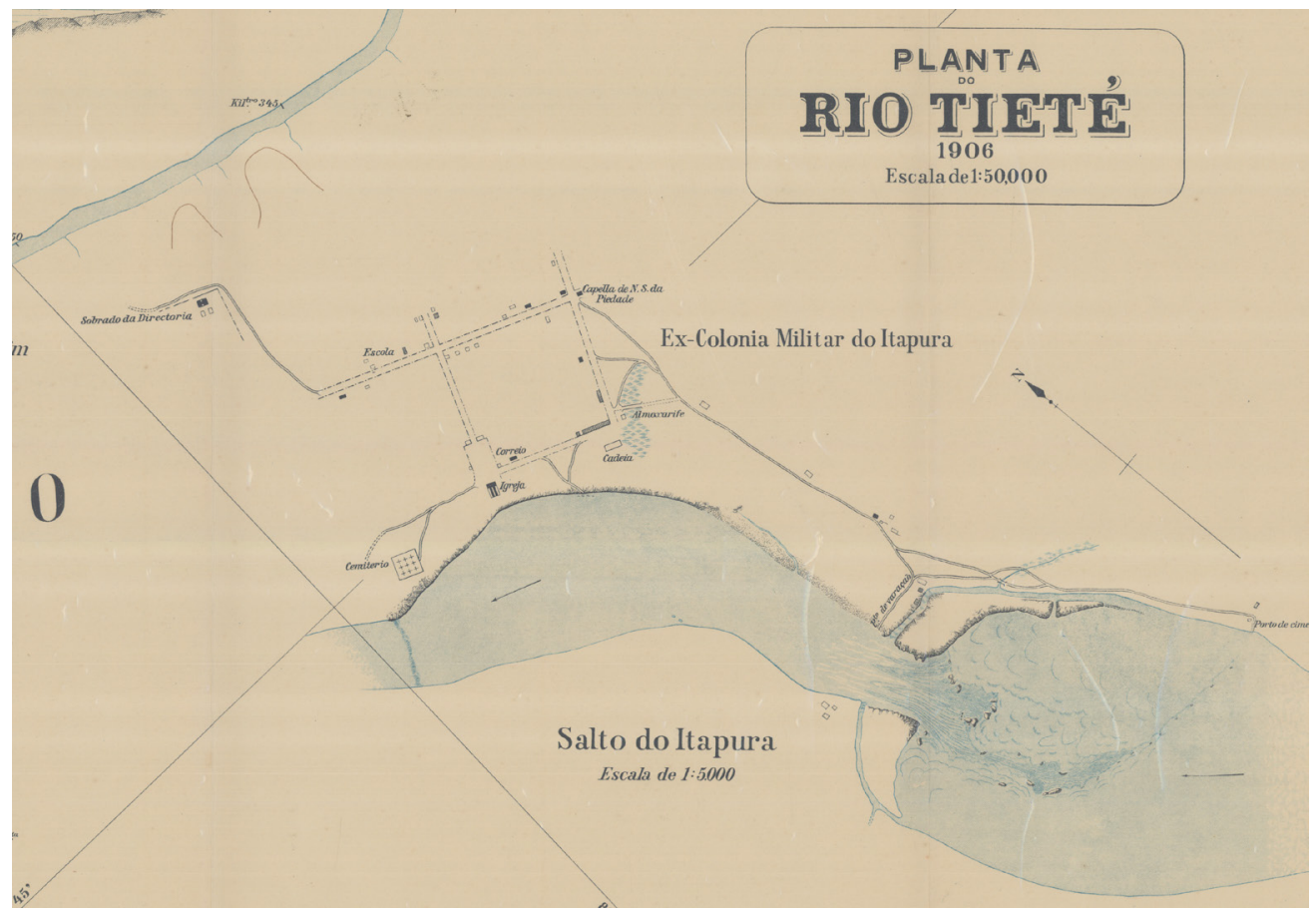

Figura 17 - Detalhe da figura 16. Notar a planta da "Ex-Colônia Militar do Itapura". Fonte: Exploração do Rio Tieté. Acervo do Centro Museu Geológico do Instituto Geológico de São Paulo, folha VIII, editado pelos autores.

No "Relatorio apresentado pelo Engenheiro Jorge Black Scorrar, chefe da turma", consta a descrição de ruínas das ex-colônias militares de ltapura e Avanhandava. A transcrição a seguir contém algumas informações sobre ltapura, em 1905:

Dos 90 edifícios que existiam na occasião de sua extincção encontram-se apenas 10 que são habitados, na sua maioria, por ex-colonos que alli se deixaram ficar depois da retirada da força e dos funccionarios federaes. Os outros que foram completamente destelhados por pessoal de Matto-Grosso acham-se completamente em estado de ruinas. Todos elles eram construidos de madeira com enchimento de tijolo e os dos funccionarios tinham commodos assoalhados e forrados, e eram rebocados e caiados. $\bigcirc$ unico edificio que se encontra ainda em bom estado e que tem escapado á devastação dos moradores de Matto-Grosso é o chalet do Director com dois pavimentos, todo construido de tijolos e com todos os commodos forrados, assoalhados e empapelados. Este edificio terá fatalmente o mesmo destino que os outros por não haver zelador encarregado de sua conservação; pois o matagal já attingiu a altura do pavimento superior e com o tempo cobrirá todo elle.

Chega-se á entrada lateral do edificio por uma picada aberta desde o portão em frente ao mesmo. No primeiro salão da entrada encontra-se um grande armario encostado a uma das paredes, onde achava-se coordenado todo o archivo da ex-colonia; esse archivo, po- 
rém, encontrámol-o espalhado pelo soalho numa promiscuidade revoltante. Não pudemos averiguar qual o auctor ou auctores de semelhante vandalismo. É, porém, de lastimar que tivessem abandonado o archivo de um estabelecimento d'aquella ordem. $O$ edificio da igreja que está construido na praça [Coronel Lima] com os fundos para o lado do rio acha-se em ruinas, já com falta de uma torre e com a outra em estado de não supportar a primeira estação chuvosa. Parte do telhado do frontespicio foi levado pela quéda da torre. $O$ antigo coreto ao lado da igreja acha-se em estado relativamente bom. ${ }^{80}$

○uarto desenho (figura 18) está reproduzido no Relatório da Companhia Estrada de Ferro Noroeste do Brasil (Cefnob) de 1906, onde aparece novamente - "Esboço do Salto de Itapura" e, em seus arredores, a planta da "Antiga Colônia de Itapura" - realizado pelos engenheiros da Cefnob durante o levantamento do percurso proposto para a ferrovia em 1905. A seguir:

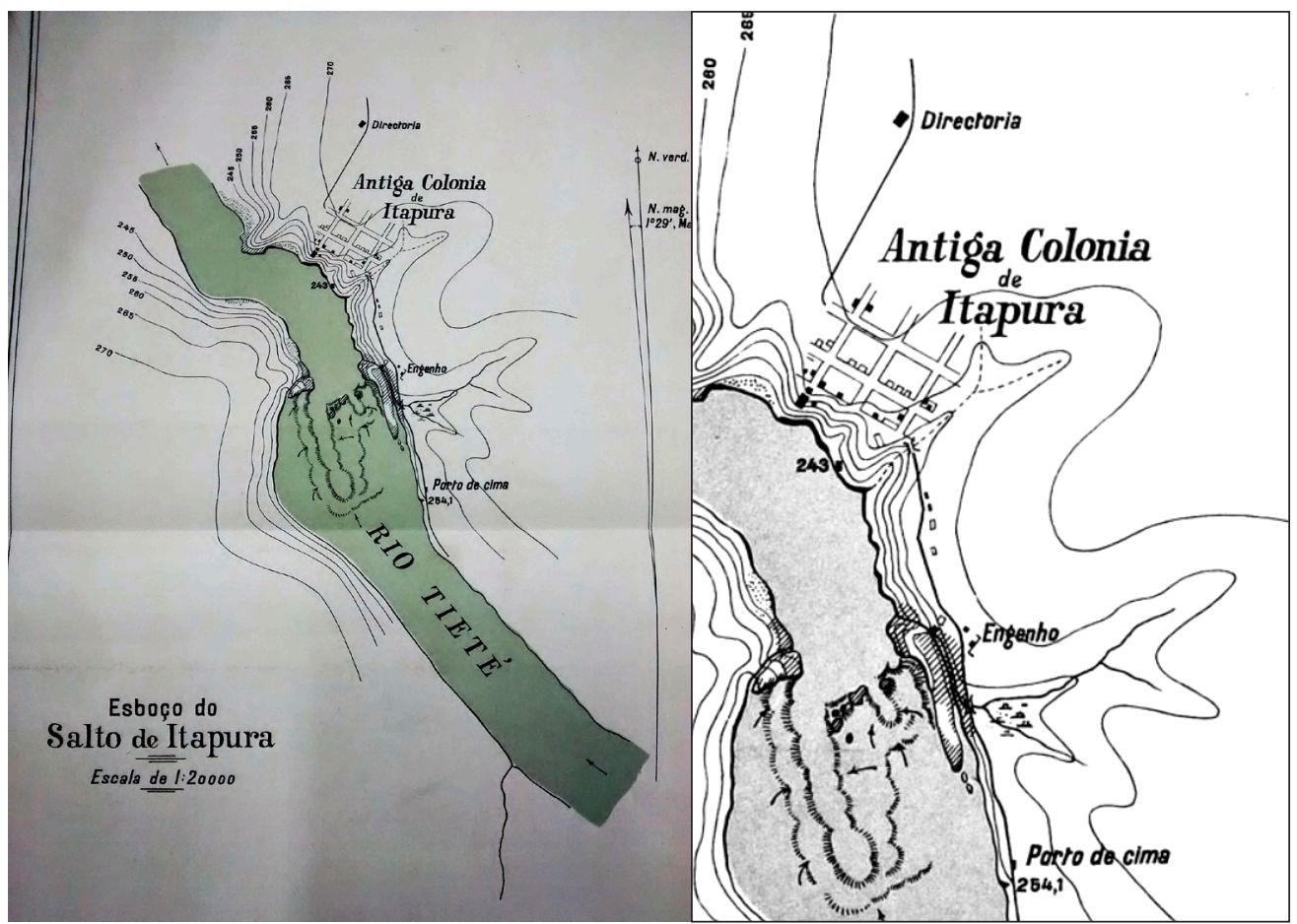

Figura 18a - À esquerda, planta da "Antiga Colônia de Itapura" no levantamento da Cefnob. Figura 18b-À direita, detalhe da figura anterior. Fonte: Relatório da Cefnob, 1906, p. 66, n 2. Acervo do Museu Ferroviário Regional de Bauru.

Sobre a região da antiga colônia militar de ltapura, trata o relatório da Cefnob:

Toda aquella extensa zona é inteiramente despovoada. É preciso chegar-se ao local da antiga colonia militar do Itapura, para encontrar talvez 3 dezenas de pessoas que restam da primitiva organização e que hoje se occupam em conduzir, ou fazer a varação,
80. Comissão Geográfica e Geológica do Estado de São Paulo (1930, p. 6-7). 
81. Relatório Cefnob (1906, p. 89). ou mesmo somente esperar as raras monções, que, de longe em longe, transportam algum sal para o estado do Mato Grosso. ${ }^{81}$

Comparando a planta elaborada por Lima com as últimas duas do século XX, é possível perceber que elas condizem entre si. Há grande semelhança no traçado do primeiro desenho da colônia de ltapura em 1878, e os dois últimos documentos encontrados, representados acima. As plantas, grosso modo, coincidem. Abaixo, um croqui para ilustrar espacialmente (figura 19) a semelhança morfológica.

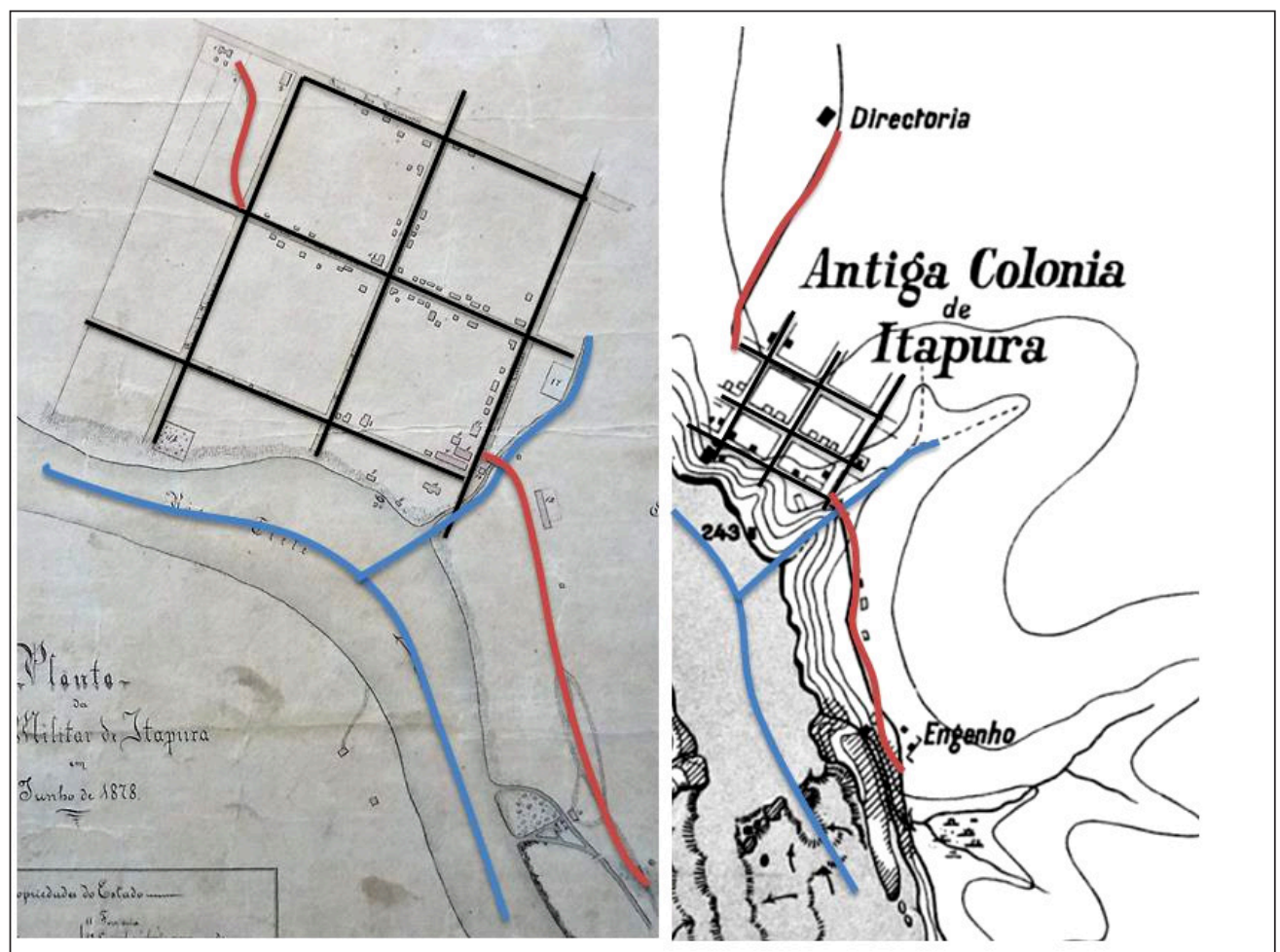

Figura 19a- ̇̀ esquerda, planta da Colônia Militar de Itapura, 1878, por Carlos Frederico de Lima. Fonte: Acervo da Fundação Biblioteca Nacional do Rio de Janeiro. Figura 19b- À direita, planta da Antiga Colônia de Itapura, 1906. Fonte: Relatório da Cefnob, 1906. Acervo do Museu Ferroviário Regional de Bauru.

Ao lado esquerdo, a primeira planta da Colônia de ltapura, de 1878, elaborada por Lima. $\bigcirc$ traçado urbano reforçado por linhas pretas, os cursos de água em azul, e as estradas sinuosas em vermelho. No lado direito, o mesmo esquema de traços e cores, agora representado sobre o desenho feito pelos engenheiros da Cefnob, em seu relatório de 1906. Com a composição acima, fica fácil observar as semelhanças. A única diferença talvez seja a 
distância da diretoria em relação ao traçado das ruas - na planta à esquerda, a casa do diretor está mais próxima; e à direita, mais distante.

Com isso, é possível afirmar que o desenho feito por Lima - se comparado com o de Giannelli - parece o mais próximo da realidade em relação ao traçado das vias e quadras, pois percebe-se a continuidade dos quadriláteros nas plantas do século XX, feitas por equipes que exploraram o Rio Tietê com olhar técnico, a CGGSP e os engenheiros da Cefnob. Assim, as ruínas encontradas pelos membros da Comissão Geográfica e Geológica de São Paulo, vistas nas fotografias expostas anteriormente, revelam ter havido empenho em construir sólidas e belas obras arquitetônicas. Junto com a planta do traçado das ruas, confirmam que o objetivo era construir uma cidade planejada, inicialmente de caráter militar, e que seria a semente de um futuro núcleo populacional civil.

\section{A DECADÊNCIA DE ITAPURA}

Apesar da pujança inicial em relação aos vultosos valores recebidos do governo imperial, Itapura é sufocada pela falta de recursos, sem base econômica e precária situação militar. Seu isolamento previsível em relação aos mercados tornou-a economicamente impotente. Continuava assim Piracicaba a ser o centro fornecedor, mas mantendo os obstáculos representados pela distância e demora das monções. Os esforços para melhorar as comunicações, como a estrada Avanhandava-ltapura, não tiveram êxito.

A terra inculta embora ubérrima; a dificuldade na remessa de verbas; a dependência de centros distantes, tudo isso fazia do ltapura, desde seu início, uma péssima propaganda, dificultando a presença de elementos que the engrossassem a população e o ajudassem na autonomia econômica. ${ }^{82}$

Ainda para a autora, a maleita foi o flagelo daqueles sertões e uma das causas da estagnação da colônia Itapura e da colonização da área nessa tentativa inicial:

Se a situação da Colônia era topograficamente ideal, como afirmava o oficial que a escolheu, o local não possuía a salubridade que ele esperava. A área do Tietê seduziu Azevedo, fazendo-o duvidar de todas as notícias que sobre a maleita the davam. Julgava-as exageradas e sem fundamento [...] $\bigcirc$ ano de 1860 foi calamitoso no Estabelecimento Naval e Colônia Militar do Itapura. Os anofelinos - transmissores da malária - atacaram agressivamente quase toda a 
83. Ibid., p. 135-137.

84. Wood (1972, p. 88).

85. Gonzaga da Silva (2017, p. 189). população. Eram 66 as pessoas atingidas pela doença endêmica [...] foi grande o número de mortes por maleita: 12, incluindo o sacerdote [...] Era esse o preço do pioneirismo. ${ }^{83}$

Em relação às baixas ocorridas nas colônias militares, de acordo com David Wood, ${ }^{84} 28$ pessoas morreram na Colônia de Urucu em 1865 pela falta de médicos e remédios; em 1873 foram registrados 149 casos de doenças na Colônia de São Pedro de Alcântara do Gurupi, que tinha 289 habitantes; a Colônia Pimenteiras sofrera com as 126 mortes causadas pelo cólera, em 1856, e mais 157 baixas no ano seguinte; durante o ano de 1857, a Colônia de Leopoldina perdera 358 residentes por moléstias, e outros 88 pereceram em 1865; 12 morreram de cólera em 1856 na Colônia Óbidos. Ainda segundo o autor, a malária, o tifo, a pleurisia, a varíola e outras doenças endêmicas e infecciosas eram muito comuns e verdadeiros perigos para as colônias.

Durante a Guerra do Paraguai, as colônias mostraram-se improdutivas na defesa e, de modo geral, revelaram-se inoperantes. $\bigcirc$ isolamento de ltapura e Avanhandava, que teoricamente seriam pontos de conexão com as colônias de Mato Grosso, uma vez que não foram concluídas as estradas de ligação entre elas, consideradas importantíssimas, deixou-as à margem dos acontecimentos. Além disso, havia a falta de abastecimento e víveres, o atraso no pagamento das diárias, a carência de pessoas que quisessem ir para a região, conhecendo os problemas. A longa distância, os danos e quebras dos produtos sofridos pelas viagens monçoeiras (que demoravam entre ida e volta aproximadamente oito meses), faziam com que os negociantes elevassem o preço das mercadorias.

Para Gonzaga da Silva, ${ }^{85}$ a invasão pelas tropas de Solano López e a ocupação da fronteira, em disputa, foram consequências dos erros cometidos pelo governo imperial em não promover as estratégias construídas pelo Ministério da Marinha. O Estabelecimento Naval e Colônia Militar do Itapura era uma dessas estratégias. Porém, a defesa de um território não seria garantida apenas com a assinatura de um decreto. Sobretudo quando se trata de uma estrutura naval para operações militares, que não deve ser improvisada - muito menos organizada e executada diante de tantas eventualidades. Ora, o estabelecimento requeria mão de obra qualificada, estrutura de portos e até mesmo outros postos navais para a manutenção das embarcações, combustível como o carvão, armamentos para navios, oficiais e praças, além de outros materiais.

Não era possível assegurar o território apenas no âmbito do discurso. As práticas discursivas deveriam ser empregadas em conjunto com as medidas concretas. $\bigcirc$ poder políitico deveria reconhecer a importância dessas políticas para defender o território e desenvolver o próprio Estado, e convergir, não só para aprovar as medidas momentaneamente, mas para prover dos 
instrumentos necessários para coloca-las em prática no decorrer dos anos. A defesa do território não seria alcançada apenas com a colocação de novos estabelecimentos militares. ${ }^{86}$

Dessa forma a autora explicita que era necessária a atenção do Império nos investimentos coloniais referentes à economia, incentivo à ocupação da população, construção de vias de integração - através de rios e estradas -, fatores que iriam auxiliar diretamente no desenvolvimento desses postos militares. Já em 1866 o conselheiro João da Silva Carrão, presidente da Província de São Paulo, declarava a inutilidade desses estabelecimentos, "sorvedouros de dinheiros públicos". ${ }^{87}$ Foi transferida assim, posteriormente ao conflito (1870), para a administração do Ministério da Guerra que, por não considerar a colônia uma prioridade, praticamente a abandona desde estão:

Sua inutilidade foi logo notada, e por influência de alguns ministros da marinha em 1870, extinguiu-se a base naval e o pequeno arsenal da marinha; do seu destino frustrado só restou a estrutura metálica da canhoneira Tamandatahy, como um fantasma, encravada nos entulhos do Tietê, antes da inundação visível no período da vazante, amedrontava os incultos moradores que lá se estabeleceram depois da extinção da colônia. ${ }^{88}$

Por último, foram diversos os fatores que culminaram na extinção da Colônia pelo governo republicano em 1895. O tempo revelou que o plano de ocupar as extensas fronteiras exigia infinitamente mais recursos materiais e humanos do que o jovem império brasileiro era capaz de fornecer. Uma a uma, as colônias estagnaram e foram abandonadas. A enormidade de tarefas empreendidas, aliadas à deficiência dos recursos disponíveis, frustrou os esforços do governo a cada momento. Ao criar esses tipos de estabelecimentos, depositavam-se neles muitas esperanças, mas eles acabaram se tornando mais dependentes, frágeis e menos autônomos do que o previsto.

Conforme Wood, ${ }^{89}$ os assentamentos foram mais dispendiosos do que o previsto. As verbas destinadas eram insuficientes. A mão de obra era escassa. Diretores das colônias verdadeiramente capacitados, qualificados e honestos, eram raridade. Com a falta de recursos materiais (suprimentos), e recursos humanos (falta de população e praças do exército), além de periodicamente estarem sujeitas às doenças, maleitas e desastres naturais, as colônias mostraram-se pouco atraentes para a maioria dos colonos em potencial. Aqueles que permaneceram no isolamento das colônias durante algum período de tempo encontraram pouco para encorajar suas energias. Em 1913, o governo "finalmente abandonou as colônias sobreviventes a seu próprio destino". ${ }^{90}$
86. Ibid., p. 188.

87. $\operatorname{CESP}(1988$, p. 12)

88. Silva (op. cit., p. 140).

89. Wood (op. cit., p. XII).

90. Ibid. 
91. Cf. Schwarcz (1999).

92. Para saber mais sobre o projeto de restauro, cf. o sítio: <https://bit. ly/38UnXk8>.

93. Para saber mais, cf. reportagem no sítio: <https:// bit.ly/2vD4kyF>.

\section{O LEGADO}

Da velha colônia militar quase nada restou. Publicamente (e erroneamente) conhecida como "Palácio do Imperador" devido à "lenda" de que D. Pedro II, o monarca nos trópicos, para usar expressão de Schwarcz, ${ }^{91}$ pisou ali em algum momento da segunda metade do século XIX - a casa do diretor foi o único edifício que sobreviveu à inundação ocorrida na década de 1960 com a construção da barragem de Jupiá. Como já mencionado anteriormente, foi tombado pelo Condephaat em 1969 e resistiu bravamente como baluarte desde então. Depredada e maltratada por muito tempo, somente no século XXI foi alvo de projeto de restauro, ${ }^{92}$ proposto por edital da Secretaria de Estado da Cultura em 2012-2013. As últimas notícias são animadoras: o recurso superior a $R \$ 1$ milhão proveniente do Fundo Estadual de Defesa dos Interesses Difusos (FID) foi aprovado pela Secretaria da Justiça e da Defesa da Cidadania para investir-se na recuperação do edifício. ${ }^{93}$

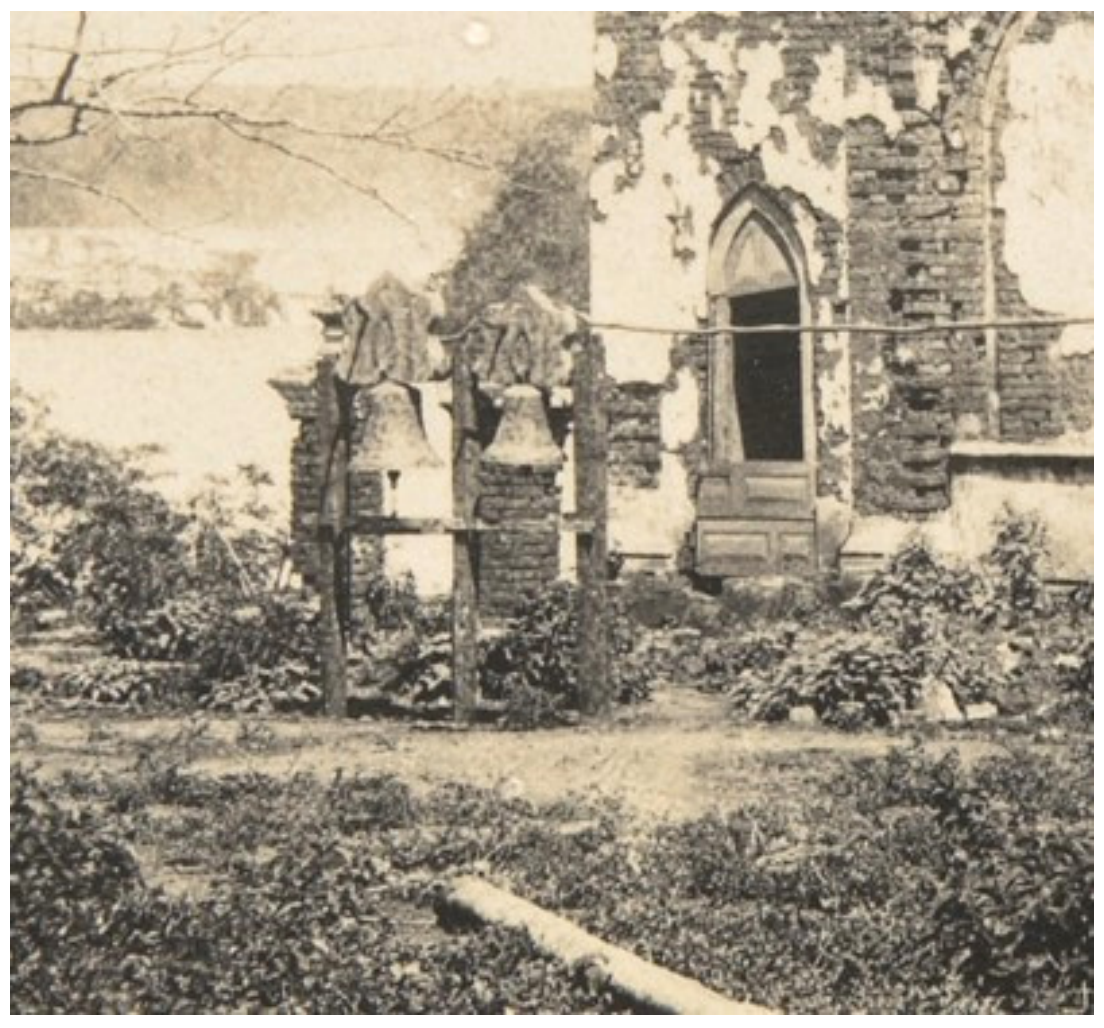

Figura 20 - Detalhe dos sinos da Igreja da Colônia Militar do Itapura, 1905. Fonte: Exploração do Rio Tieté. Álbum de fotografias. Acervo do Centro Museu Geológico do Instituto Geológico de São Paulo. 


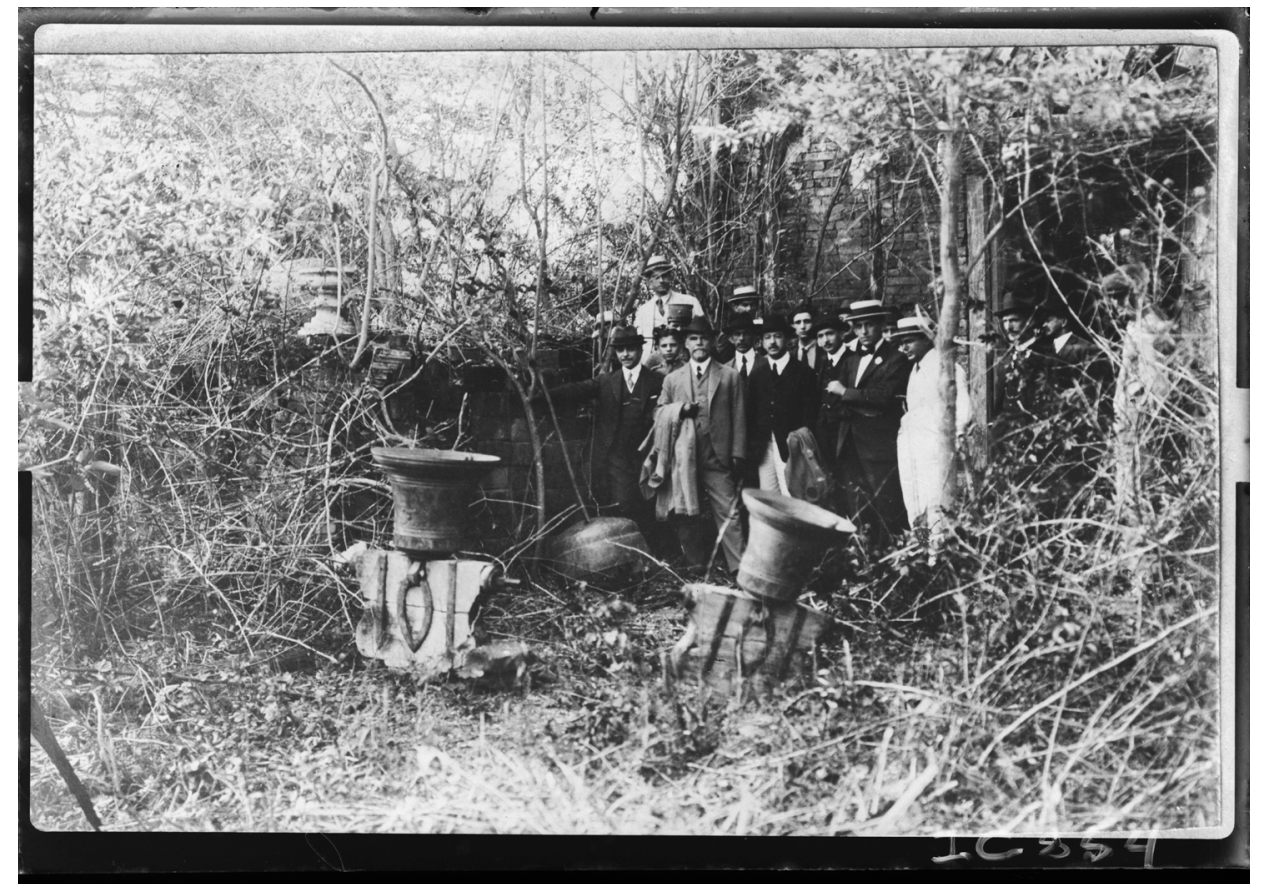

Figura 21 - Excursão à ltapura. Em primeiro plano, Washington Luís em visita como presidente do Estado de São Paulo (c. 1922). Notar os sinos da igreja. Fonte: Acervo do Museu Paulista (IC: 1-00854-0000-0000). Foto: Helio Nobre/José Rosael.

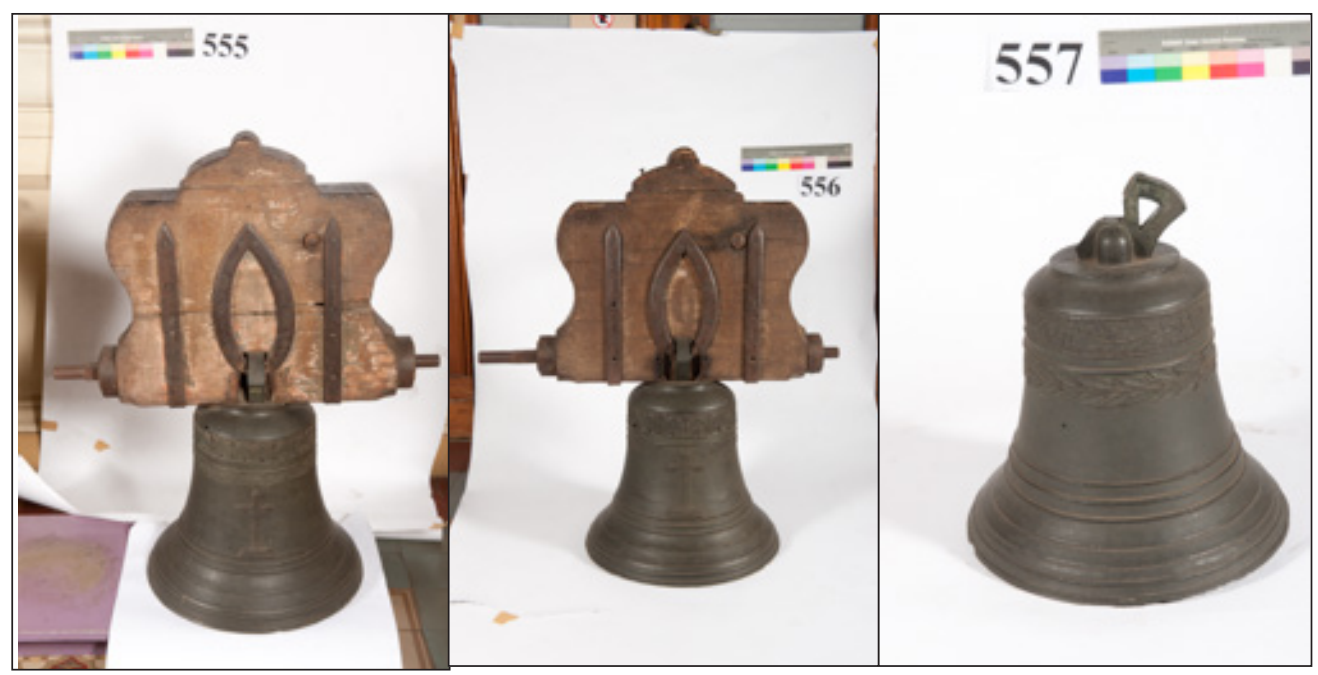

Figura 22 - Os três sinos da igreja. Fonte: Acervo do Museu Paulista. (RG: 1-13-02-000-00555-0000; 556 e 557, respectivamente). Fotos: Helio Nobre/José Rosael.

Além da casa do diretor, em relação à cultura material, alguns resquícios da colônia militar foram preservados. São eles: três sinos da antiga igreja e um canhão 
- todos em bronze e pertencentes ao acervo do Museu Paulista (ver figuras 22 e 24). Acreditamos que o presidente do Estado de São Paulo, Washington Luís, em visita a Itapura (ver figura 21, c. 1922) em uma de suas incursões de reconhecimento pelo interior do estado, recuperou as peças levando-as para o museu. Na figura 20, fotografia tirada em 1905 pela Comissão Geográfica e Geológica em expedição ao Rio Tietê, é possível observar os dois sinos em frente às ruínas da igreja. Ademais, pode-se dizer que o legado de Itapura, com sua organização espacial e edilícia apresentada aqui, representou um marco pouco conhecido no urbanismo brasileiro e que ainda precisa ser mais bem estudado (assim como Avanhandava).

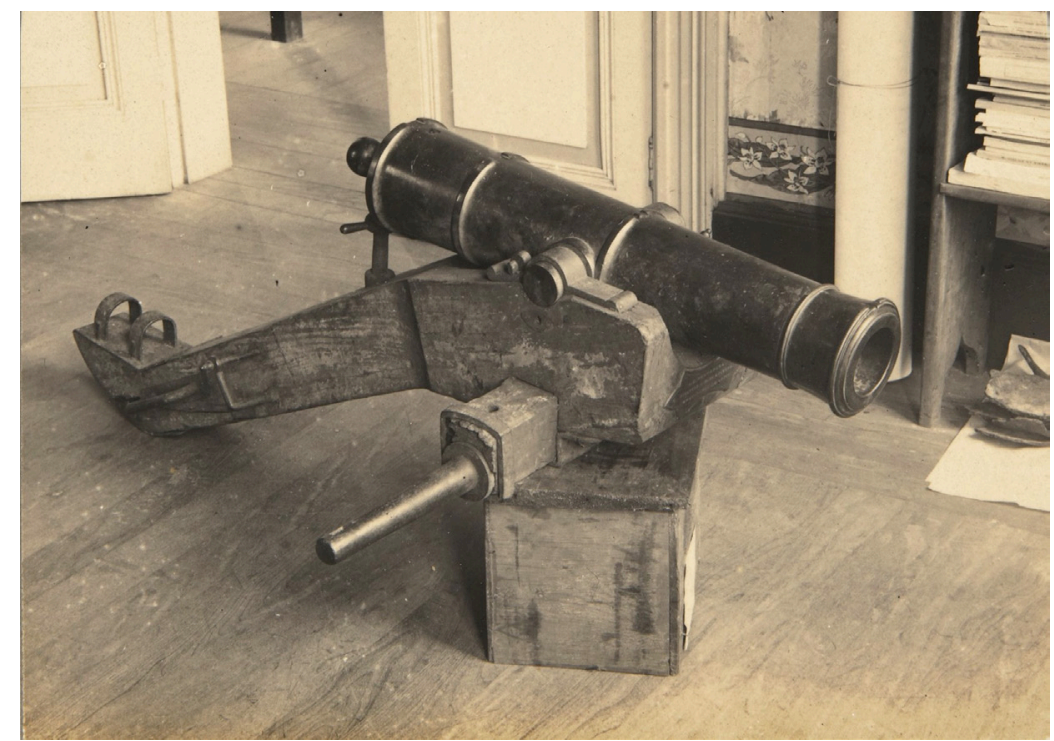

Figura 23 - Canhão da Colônia Militar do ltapura, 1905. Fonte: Exploração do Rio Tieté. Álbum de fotografias. Acervo do Centro Museu Geológico do Instituto Geológico de São Paulo.

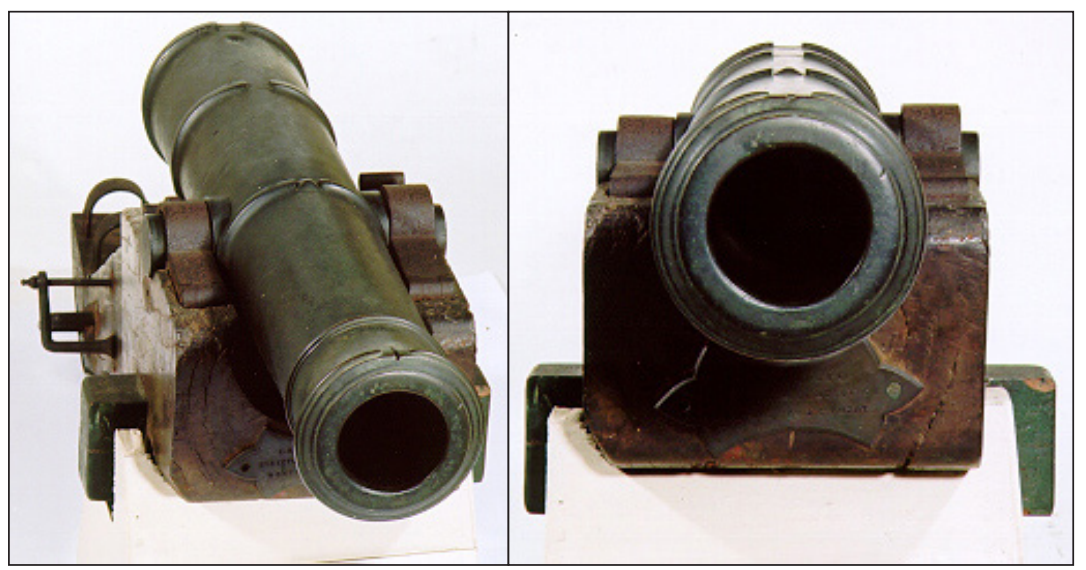

Figura 24 - Canhão. Fonte: Acervo do Museu Paulista. (RG: 1-1 5-02-000-03737-00-00). Foto: Helio Nobre/José Rosael. 


\section{CONSIDERAÇÕES FINAIS}

De fato, no isolado "sertão do Itapura" ergueu-se um núcleo urbano com traçado preestabelecido. Algumas de suas construções isoladamente, arrojadas para o local e época, poderiam superar a maioria das edificações de Sant'Ana do Paranaíba e Constituição (Piracicaba), centros com os quais matinha relações comerciais. A realidade é que Itapura pode ser considerada uma exceção: a riqueza arquitetônica atingida por seus edifícios deu-lhe caráter único entre as demais colônias militares brasileiras. Buscou-se demonstrar a precedência do urbano, e sobretudo, do planejamento urbano-militar, numa área considerada muito afastada da capital da província, em meados do século XIX.

Porém, sabe-se que a região das duas colônias militares paulistas, Avanhandava e ltapura, só retomará a ocupação sistematizada a partir da construção da Companhia Estrada de Ferro Noroeste do Brasil, no início do século XX. Essa ferrovia indicou a direção fundamental do crescimento da vida rural e urbana na região, além de servir ao transporte e escoamento em grande escala da produção cafeeira. Em 1968, já totalmente abandonada, seus materiais consumidos pelos vizinhos da antiga colônia, - Estabelecimento Naval e Colônia Militar do Itapura assiste a suas ruínas arqueológicas e seu passado urbano serem submersos pelas águas da represa de Jupiá. $\bigcirc$ sacrifício do antigo núcleo urbano, e da própria beleza do salto do ltapura - assim como aconteceu posteriormente com Avanhandava (1982) - talvez não tenham sido em vão. A energia elétrica produzida na área pode representar o início de uma nova era para essa região e para o estado. Um marco, novamente, do já conhecido "progresso".

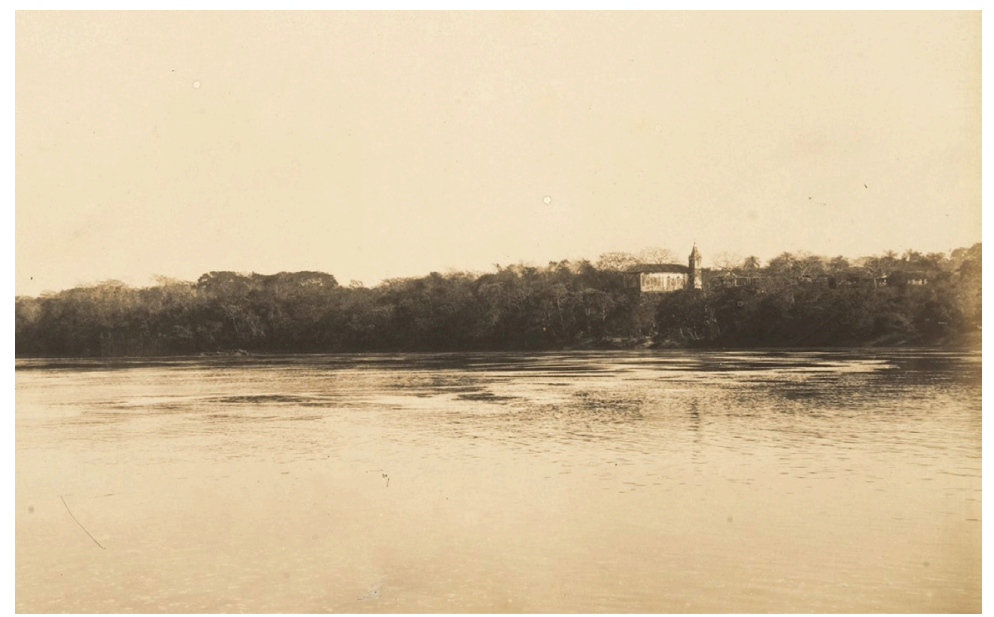

Figura 25 - Fotografia do Rio Tietê pela CGGSP em 1905. Nota-se, ao longe, o despontar da igreja de ltapura em meio à mata e outras singelas construções à direita. Fonte: Exploração do Rio Tieté. Álbum de fotografias. Acervo do Centro Museu Geológico do Instituto Geológico de São Paulo. 


\section{REFERÊNCIAS}

FONTES ICONOGRÁFICAS

COMISSÃO GEOGRAPHICA E GEOLOGICA DO ESTADO DE S. PAULO. Exploração do Rio Tieté. (Barra do Rio Jacaré-Guassú ao Rio Paraná). Publicado no período presidencial do Dr. Jorge Tibiriçá sendo Secretario da Agricultura o Dr. Carlos J. Botelho, 1905. $3^{\text {a }}$ ed. São Paulo: Typographia Brazil de Rothschild\& Cia., 1930.

GIANNELli, Ercole. Provincia de S. Paulo: Colônia Militar de Itapura. São Paulo: J. Martin, 1885. Descrição: Planta; 74 x 113cm., desenhado fora de escala. (Acervo cartográfico Biblioteca Nacional do Rio de Janeiro).

LIMA, Carlos Frederico de. Planta da Colônia Militar de Itapura em junbo de 1878. Rio de Janeiro: [s. n.], 1878. Descrição: Mapa manuscrito; 45,5 x 36,5cm., Escala 1:4000. (Acervo cartográfico - Biblioteca Nacional do Rio de Janeiro).

MüLlER, Daniel Pedro. Mappa Chorographico da Provincia de São Paulo, 1841. In: BEIER, José Rogério. Biografia de um mapa: A trajetória do primeiro mapa impresso da província de São Paulo (1835-1842). In: Anais do V Simpósio Luso-Brasileiro de cartografia histórica. Petrópolis, RJ, nov./2013.

NOBRE, Helio; ROSAEL, José. Canhão. Acervo do Museu Paulista. (RG: 1-15-02-000-03737-0000). 1. Fotografia.

NOBRE, Helio; ROSAEL, José. Casa do diretor, c. 1905. Acervo do Museu Paulista (IC: 1-036110000-0000). 1. Fotografia.

NOBRE, Helio; ROSAEL, José. Excursão à Itapura. Washington Luís em visita como presidente do Estado de São Paulo (c. 1922). Acervo do Museu Paulista (IC: 1-00854-0000-0000). 1. Fotografia.

NOBRE, Helio; ROSAEL, José. Igreja da Colônia Militar de Itapura, c. 1905. Acervo do Museu Paulista (IC: 1-03610-0000-0000). 1. Fotografia.

NOBRE, Helio; ROSAEL, José. Os três sinos da igreja. (c. 1922). Acervo do Museu Paulista. (RG: 1-13-02-000-00555-00-00; 556 e 557, respectivamente). 1. Fotografia. 
PLANTA da situação da colônia militar de Itapura, 1936. Secretaria de Estado da Cultura, Condephaat, processo $\mathrm{n}^{\circ} 12318 / 69$.

FONTES IMPRESSAS

AZEVEDO, Antonio Mariano de. Relatório do primeiro tenente d'armada sobre os exames de que foi incumbido no interior da província de S. Paulo. Rio de Janeiro: Typ. Peixoto, 1858.

BRASIL. Collecção das Leis do Imperio do Brasil de 1850. Tomo XI. Parte I. Rio de Janeiro: Typographia Nacional, 1850.

BRASIL. Colleção das Leis do Imperio do Brasil de 1854. Tomo XVII. Parte II. Rio de Janeiro: Typographia Nacional, 1854.

BRASIL, Collecção das Leis do Imperio do Brasil de 1858. Tomo XIX, Parte II. Rio de Janeiro: Typographia Nacional, 1858.

RELATÓRIO da Directoria da Companhia Estrada de Ferro Noroeste do Brazil apresentado á Assembléa Geral Ordinaria realisada em 11 de junho de 1906. Rio de Janeiro: Typographia de Heitor Ribeiro \& C., 1906.

LIVROS, ARTIGOS E TESES

BACELlAR, Carlos de Almeida Prado. As famílias de povoadores em áreas de fronteira da capitania de São Paulo na segunda metade do século XVIII. Revista brasileira de estudos de população, Belo Horizonte, v. 34, n. 3, p. 549-565, set./dez., 2017, p. 550.

BARROS, Fausto Ribeiro de. Itapura. Ex-Colônia Militar e Estabelecimento Naval. In: Revista do Instituto Histórico e Geográfico de São Paulo (IHGSP), São Paulo: Gráfica Canton Ltda., Volume LIV, p. 279-312, 1957.

BEIER, José Rogério. Biografia de um mapa: A trajetória do primeiro mapa impresso da província de São Paulo (1835-1842). In: Anais do V Simpósio Luso-Brasileiro de cartografia bistórica. Petrópolis, RJ, nov./2013.

BENEVOLO, Leonardo. História da cidade. $7^{\mathrm{a}}$ ed. São Paulo: Perspectiva, 2019. 
CAlvinO, Italo. As cidades invisíveis São Paulo: Companhia das Letras, 1990.

CESP. Salto do Avanhandava: história e documentação. Orentino Martins. Penápolis: Companhia Energética de São Paulo1988.

CINTRA, Jorge Pimentel; BEIER, José Rogério; RABELO, Lucas Montalvão. Affonso de Taunay e as duas versões do mapa de D. Luis de Céspedes Xeria (1628). Anais do Museu Paulista: História E Cultura Material, São Paulo, v. 26, n. 33, p. 1-53, 2018.

DERNTL, Maria Fernanda. Método e Arte: criação urbana e organização territorial na capitania de São Paulo, 1765-1811. Tese (Doutorado) - Faculdade de Arquitetura e Urbanismo da Universidade de São Paulo FAU-USP, São Paulo, 2010.

DI CREDDO, Maria do Carmo Sampaio. Terras e índios. Propriedade da terra no Vale do Paranapanema. São Paulo: Arte \& Ciência, 2003.

GHIRARDELLO, Nilson. Estabelecimento Naval e Colônia Militar do Itapura, ápice do pensamento urbanístico-militar do império brasileiro. In: Anais do IX Seminário de História da Cidade e do Urbanismo - IX SHCU. São Paulo, 4 a 6 de Setembro de 2006.

GONZAGA DA SILVA, Jéssica de Freitas e. "Na paz, cumpre-se preparar a guerra": a Armada Imperial e a defesa da fronteira da província do Mato Grosso contra a República do Paraguai (1852-1865). 2017. Dissertação (Mestrado) - Programa de Pós-Graduação em Estudos Marítimos, Escola de Guerra Naval, Rio de Janeiro, 2017.

HOLANDA, Sérgio Buarque de. Monções e Capítulos de expansão paulista. Laura de Mello Souza, André Sekkel Cerqueira (Orgs.). 4ª ed. São Paulo: Companhia das Letras, 2014.

JANKE, Leandro Macedo. Duarte da Ponte Ribeiro: Território e territorialidade no império do Brasil. 2014. Tese (Doutorado) - Universidade de São Paulo, Departamento de Geografia Humana da Faculdade de Filosofia, Letras e Ciências Humanas, São Paulo, 2014.

MACAULAY, David. Construção de uma cidade romana. São Paulo: Martins Fontes, 1989.

MATTOS, Ilmar Rohloff de. Do Império do Brasil ao Império do Brasil. In: Faculdade de Letras da Universidade do Porto. (Org.). Estudos em homenagem a Luís Antonio de Oliveira Ramos. Porto: Universidade do Porto, 2004. v. 2, p. 727-736.

MONBEIG, Pierre. Pioneiros e fazendeiros de São Paulo. São Paulo: Hucitec; Polis, 1984. 
MUMFORD, Lewis. A cidade na história: suas origens, desenvolvimento e perspectivas. $2^{\mathrm{a}}$ ed. São Paulo: Martins Fontes, 1982.

NEME, Mário. História da Fundação de Piracicaba. Piracicaba, SP: Editora Equilíbrio; Instituto Histórico e Geográfico de Piracicaba, 2009.

NEME, Mário. Piracicaba no século XVIII. São Paulo: Equilíbrio, 2010.

OLIVERA, Maria Luiza Ferreira de. O Exército e "a difícil luta contra a independência dos homens do campo": embates na construção do Estado no Brasil, 1840-1870. In: SOUZA, Adriana Barreto de, et. al. (Orgs.) Pacificar o Brasil, das guerras justas às UPPs. São Paulo: Alameda, 2017. p. 197-224.

SCHWARCZ, Lilia Moritz. As barbas do imperador: D. Pedro II, um monarca nos trópicos. $2^{\mathrm{a}}$ ed. São Paulo: Companhia das Letras, 1999.

SILVA, Maria Apparecida. Itapura: Estabelecimento Naval e Colônia Militar (1858-1870). 1972. Tese (Doutorado) - Faculdade de Filosofia, Letras e Ciências Humanas da Universidade de São Paulo, São Paulo, 1972.

WOOD, David Lyle. Abortive panacea: Brazilian military settlements, 1850 to 1913 . A dissertation submitted to the faculty of the University of Utah in partial fulfillment of the requirements for the degree of Doctor of Philosophy - Department of History, University of Utah, 1972.

SITES

Museu Paulista da USP. Acervo de iconografia e objetos - Disponível em: <https://bit.ly/33FKuhC>. Acesso em: 10 out. 2019.

Artigo apresentado em 05/12/2019. Aprovado em 25/03/2020.

\section{(cc) BY}

All the contents of this journal, except where otherwise noted, is licensed under a Creative Commons Attribution License 